\title{
Analisis Efisiensi Pembuatan Tas Bordir Aceh(Studi Kasus di Kecamatan Muara Batu Kabupaten Aceh Utara)
}

\author{
Nova Yani ${ }^{* a}$, Hijri Juliansyah ${ }^{* b}$ \\ * Fakultas Ekonomi dan Bisnis Universitas Malikussaleh \\ a Corresponding author:novaeduqation1997@gmail.com \\ bhijri.juliansyah@gmail.com
}

\section{A R T I C L E I N F O R M A T I O N}

Keywords:

Making Aceh Embroidery Bag,

Data Envelopment Analysis (DEA), Efficiency, CRS, VRS, Output

Oriented

\section{A B S T R A C T}

This study aims to analyze and find out how much the level of efficiency in making Aceh embroidery bags (Case Study in Muara Batu District, North Aceh Regency). The data used in this study are primary data obtained from 20 Aceh embroidery bag business units. This research uses Data Envelopment Analysis (DEA) method. From the Constant Return to Scale (CRS - Output Oriented), results showed that only four business units were efficient while sixteen business units were inefficient. Through the results of Variable Return to Scale (VRS - output oriented), there were seven efficient business units, while thirteen more business units were inefficient.

\section{PENDAHULUAN}

Usaha kerajinan merupakan usaha produktif di sektor non pertanian baik untuk mata pencaharian utama ataupun sampingan.Usaha kerajinan membutuhkan kemampuan dan kreatifitas.Sebagai salah satu usaha ekonomi, maka usaha kerajinan dikelompokkan kedalam katagori usaha industri kecil atau usaha yang berskala kecil. Keberadaan suatu usaha industri di suatu wilayah tentu akan mempengaruhi kondisi sosial ekonomi dengan penyerapan tenaga kerja dari masyarakat sekitarnya. Penyerapan tenaga kerja merupakan jumlah tertentu dari tenaga kerja yang digunakan dalam suatu unit usaha tertentu. Hal tersebut secara tidak langsung akan meningkatkan kesejahteraan dengan memberikan upah terhadap pekerjanya yang berasal dari pendapatan usaha industri kecil tersebut.

Industri tidak terlepas dari usaha untuk meningkatkan produktivitas tenaga kerja manusia untuk menjadi yang lebih baik. Pembangunan di bidang industri harus dikembangkan secara bertahap melalui iklim yang merangsang bagi penanam modal dan penyebaran pembangunan industri yang disesuaikan dengan potensi yang dimiliki oleh masing-masing daerah (Todaro, 2000dalam Wulandari \& Darsana, 2017). Industri yangberskala kecil merupakan salah satu solusi bagi sebagian besar masyarakat lokal untuk mendapat pekerjaan. Hal tersebut disebabkan karena pada umumnya industri kecil lebih memperioritaskan untuk mengambil pekerja dari lingkungan sekitarnya dan tidak terlalu dituntut untuk memiliki pendidikan tinggi. Hal yang demikian juga terjadi di Desa Ulee Madon Kecamatan Muara Batu Kabupaten Aceh Utara yang selama ini dikenal sebagai sentra kerajinan Bordir Aceh.

Usaha kerajinan Bordir Aceh adalah salah satu usaha kerajinan yang memproduksi berbagai jenis souvenir yang bergambarkan atau menggunakan bordir khas Aceh.Industri kerajinan ini biasanya dilakukan dirumah-rumah atau dikatakan industri rumah tangga. Di Kecamatan Muara Batu industri ini akan mudah dijumpai, hampir disetiap rumah terdapat pengerjaan Bordir Aceh. Berdasarkan data dari Rencana Pembangunan Jangka Menengah Gampong (RPJMG) dapat diketahui jumlah industri rumah tangga kerajinan bordir aceh sebanyak 28 unit usaha dengan jumlah tenaga kerja total 410 orang.Oleh karenaitu sektor industri kerajinan Bordir Aceh semakin menjadi tumpuan bagi masyarakat.Meskipun usaha tersebut bersifat 
industri rumah tangga, tapi hal ini membawa hal positif terhadap kondisi sosial ekonomi masyarakat sekitar.Perkembangan industri Bordir Aceh merupakan suatu kegiatan untuk meningkatkan kesejahteraan hidup masyarakat menjadi lebih maju dan lebih bermutu demi meningkatkan pendapatan.

Kemajuan usaha tas border Aceh di Kecamatan Muara Batu Kabupaten Aceh Utara selama ini masih tetap eksis walaupun terhimpit dari ekonomi global. Pengembangan usaha tas border Aceh di Kecamatan Muara Batu Kabupaten Aceh Utara lebih diarahkan untuk meningkatkan kemampuan usaha. Kondisi saat ini, usaha tas border Aceh di Kecamatan Muara Batu Kabupaten Aceh Utara masih mengalami kendala, terutama kendala persaingan tas dari luar daerah maupun dari luar negeri yang lebih menarik minat konsumen.

Dalam pengerjaan kerajinan ini pengalaman kerja sangat diperlukan karena setiap pengalaman yang diperoleh seseorang akan membantunya dalam memberikan keterampilan dan pengetahuan khusus yang sesuai dengan jenis pekerjaan yang ditekuninya. Pada dasarnya seseorang yang melakukan jenis pekerjaan secara berulang-ulang dalam jangka waktu yang cukup lama akan menjadikan dirinya cukup terampil dalam mengerjakan pekerjaan tersebut sehingga produktivitasnya meningkat dan pendapatanpun ikut meningkat. Namun dalam industri kerajinan bordir Aceh ini tidak semua pekerja yang memiliki banyak pengalaman akan mendapatkan pendapatan yang lebih besar dibandingkan dengan pekerja yang hanya memiliki sedikit pengalaman.

Selain pengalaman kerja, produktivitas juga menentukan pendapatan pekerja.Semakin banyak produk yang dihasilkan maka semakin banyak pula pendapatan yang diterima.Namun banyaknya produk yang dihasilkan oleh pekerja industri kerajinan bordir Aceh tidak selalu memberikan pendapatan yang lebih dibandingkan pekerja yang menghasilkan sedikit produk. Hal tersebut dikarenakan tingkat kesukaran dalam pengerjaan kerajinan bordir motif Aceh berbedabeda ditambah lagi tidak semua tas yang baru siap dikerjakan akan langsung terjual selain itu kerapian serta bahan baku yang digunakan menjadi pertimbangan tersendiri oleh konsumen.

Faktor lainnya yang mempengaruhi pendapatan adalah jam kerja. Lama bekerja adalah waktu yang ditempuh seseorang untuk bekerja dalam suatu pekerjaan. Penggunaan jam kerja yang sama tidak menentukan pendapatan yang sama pada pekerja industri kerajinan bordir aceh karena penggunaan jam kerja yang sama tidak selalu menghasilkan jumlah produk yang sama. Hal tersebut menjadi salah satu penyebab adanya perbedaan pendapatan antara para pekerja dari segi tingkat jam kerja.

Penelitian - penelitian yang mengindentifikasikan penggunaan faktor-faktor produksi terhadap pendapatan telah banyak dilakukan dengan menggunakan analisis DEA seperti (Dari, 2018), (Marta \& Erza, 2010) (Andriyani et al., 2020) yang menggunakan variabel jumlah tenaga kerja dan jumlah nilai produksi, selanjutnya variabel produksi telah diteliti oleh (Setiawan \& Prajanti, 2011), kemudian penelitian mengenai variabel modal dan nilai produksi usaha telah dilakukan oleh (Wajdi, 2012), dan penelitian mengenai variabel jumlah biaya dilakukan oleh (Winanthi, 2018). Menurut hemat peneliti, kajian dari efesiensi produksi pembuatan tas bordir Aceh masih sedikit dijumpai.

Berikut data variabel yang digunakan pada penelitian ini yang dapat dilihat pada tabel 1 berikut.

Tabel 1

Usaha Tas Bordir Aceh di Desa Ulee Madon

Kecamatan Muara BatuKabupaten Aceh Utara

\begin{tabular}{|c|c|c|c|c|c|c|}
\hline \multirow[b]{2}{*}{$\stackrel{\ominus}{Z}$} & \multirow[b]{2}{*}{$\begin{array}{c}\text { Pemilik/ } \\
\text { Nama } \\
\text { Usaha }\end{array}$} & \multicolumn{3}{|c|}{ Input } & \multicolumn{2}{|c|}{ Output } \\
\hline & & 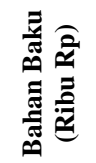 & 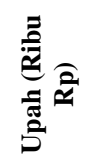 & 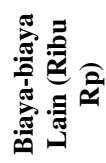 & 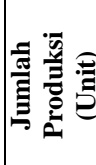 & 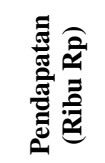 \\
\hline 1 & Nyak Cut & 23.080 & 38.000 & 10.800 & 510 & 127.500 \\
\hline 2 & Maryana & 20.790 & 31.000 & 8.400 & 489 & 122.250 \\
\hline 3 & Jarjani & 23.220 & 54.000 & 12.000 & 472 & 118.000 \\
\hline 4 & Tabina & 19.770 & 36.000 & 10.800 & 489 & 122.250 \\
\hline 5 & Nadia & 20.420 & 26.000 & 9.600 & 498 & 124.500 \\
\hline 6 & Nurjani & 18.710 & 36.000 & 10.800 & 499 & 124.750 \\
\hline 7 & Marzuki & 22.860 & 36.000 & 10.800 & 466 & 116.500 \\
\hline 8 & Sanusi & 20.620 & 48.000 & 12.000 & 476 & 119.000 \\
\hline 9 & $\begin{array}{c}\text { Bungong } \\
\text { Rauza }\end{array}$ & 20.802 & 37.000 & 10.800 & 508 & 127.000 \\
\hline 10 & Jailani & 21.960 & 30.000 & 10.800 & 481 & 120.250 \\
\hline
\end{tabular}




\begin{tabular}{|c|c|c|c|c|c|c|}
11 & Nuria & 24.930 & 60.000 & 12.000 & 450 & 112.500 \\
\hline 12 & Putrona & 20.290 & 30.000 & 9.600 & 467 & 116.750 \\
\hline 13 & Pelita & 23.140 & 48.000 & 10.800 & 488 & 122.000 \\
\hline 14 & $\begin{array}{c}\text { Pelita Sri } \\
\text { Maryati }\end{array}$ & 20.160 & 36.000 & 10.800 & 459 & 114.750 \\
\hline 15 & Sanyo Bag & 20.020 & 36.000 & 10.800 & 491 & 122.750 \\
\hline 16 & $\begin{array}{c}\text { Naiart Cop } \\
\text { Tah }\end{array}$ & 24.680 & 30.000 & 9.600 & 495 & 123.750 \\
\hline 17 & Nisa & 23.520 & 42.000 & 10.800 & 495 & 123.750 \\
\hline 18 & Rolan & 18.840 & 30.000 & 8.400 & 469 & 117.250 \\
\hline 19 & Zaini & 19.940 & 48.000 & 10.800 & 478 & 119.500 \\
\hline 20 & Anwar & 18.210 & 36.000 & 10.800 & 495 & 123.750 \\
\hline
\end{tabular}

Sumber: Data Observasi, 2019

Berdasarkan keterangan dari tabel 1 bahan baku rata-rata dikeluarkan setiap tahunnya untuk pembuatan tas bordir Aceh berkisar antara Rp. 18.000.000 sampai dengan Rp. 25.000.000, untuk pengeluaran bahan baku yang paling besar yang dikeluarkan oleh usaha miliki Naiart Cop Tah sebesar Rp. 24.680.000,- sedangkan untuk pengeluaran tahunan yang paling sedikit yaitu usaha milik Anwar sebesar Rp. 18.210.000,- dan usaha milik Rolan sebesar Rp. 18.840.000,-. Untuk pendapatan bersih bila ditinjau dari pendapatan bersih yang perbulannya rata-rata pendapatan usaha pembuatan tas bordir Aceh sebesar Rp. 4.223.000,-selain bahan baku, produsen tas bordir Aceh juga membayar upah pekerja rata-rata pertahun mencapai Rp. 50.000.000. Jadi. Indikasi efiseinsi selain alokasi input yang tepat untuk menghasilkan output yang maksimal, efisiensi juga dapat dilihat dengan memperhatikan rasio keuangan antara pengeluaran dan pendapatan, salah satunya adalah jumlah produksi dan pendapatan itu sendiri, sedangkan untuk pembagian pada biaya lain terdapat pada lampiran yang tidak memungkinkan untuk sajikan pada bab ini.

Tujuan penelitian yang ingin dicapai adalah untuk menganalisis dan mengetahui seberapa besar tingkat efisiensi pembuatan tas bordir Aceh (Studi kasus di Desa Ulee Madon Kecamatan Muara Batu Kecamatan Muara Batu Kabupaten Aceh Utara).

Pada bagian kedua, penelitian ini membahas kajian teoritis yang terkait dengan variabelvariabel dalam penelitian, kemudian bagian tiga akan memaparkan metode serta alat analisis yang digunakan. Hasil perhitungan dan analisis pembahasan terkait nilai skala efisiensi serta variabel yang inefisien pada masing-masing unit usaha akan dijelaskan pada bagian empat yang selanjutkan disimpulkan dan diimplikasikan terhadap kebijakan yang dapat diambil oleh masing-masing unit usaha pembuatan tas bordir Aceh di Desa Ulee Madon Kecamatan Muara BatuKabupaten Aceh Utara pada bagian lima dan enam.

\section{KAJIAN TEORITIS}

\section{Fungsi produksi}

Fungsi produksi adalah suatu persamaan yang menunjukkan jumlah maksimum output yang dihasilkan dengan kombinasi input tertentu (Ferguson \& Gould, 1975).Fungsi produksi menunjukkan sifat hubungan di antara faktorfaktor produksi dan tingkat produksi yang dihasilkan. Faktor-faktor produksi dikenal pula dengan istilah input dan jumlah produksi selalu juga disebut sebagai output. Fungsi produksi selalu dinyatakan dalam rumus seperti berikut (Sukirno, 2012)

$$
Q=f(K, L, R, T)
$$

\section{Dimana}

$$
\begin{array}{ll}
\mathrm{K} & \text { = Jumlah stok modal } \\
\mathrm{L} & =\text { Jumlah tenaga kerja } \\
\mathrm{R} & =\text { kekayaan alam } \\
\mathrm{T} & =\text { tingkat teknologi yang digunakan. } \\
\mathrm{Q} & \text { = jumlah produksi }
\end{array}
$$

Di dalam ekonomi, pengertian fungsi produksi lainnya yaitu suatu fungsi yang menunjukkan hubungan antara hasil produksi fisik (output) dengan faktor-faktor produksi (input). Dalam bentuk matematika sederhana fungsi produksi ini dituliskan sebagai berikut (Mubyarto, 2010):

Keterangan:

$\mathrm{Y}=$ Hasil Produksi Fisik

$\mathrm{x} 1, \mathrm{x} 2, \ldots \mathrm{xn}=$ Faktor-Faktor Produksi

\section{Input}

Kegiatan dalam input produksi erat kaitannya dengan pengadaan bahan utama kegiatan produksi. Komponen-komponen dalam input produksi dalam penelitian ini adalah bahan baku, upah, model. 


\section{Bahan Baku}

Bahan baku merupakan faktor penting yang ikut menentukan tingkat harga pokok dan kelancaran proses produksi usaha. Pengertian bahan baku adalah, barang-barang yang akan menjadi bagian dari produk jadi yang dengan mudah dapat diikuti biayanya(Eddy, 2010). Secara umum mengenai bahan baku merupakan bahan mentah yang menjadi dasar pembuatan suatu produk yang mana bahan tersebut dapat diolah melalui proses tertentu untuk dijadikan wujud yang lain(Eddy, 2010)

\section{Upah}

Pengertian upah sendiri menurut Sukirno (2015) adalah pembayaran kepada pekerja-pekerja kasar yang pekerjaannya selalu berpindah pindah, seperti misalnya pekerja pertanian, tukang kayu, tukang batu dan buruh kasar.Sedangkan dalam teori ekonomi upah diuraikan sebagai pembayaran atas jasa-jasa fisik maupun mental yang disediakan oleh tenaga kerja kepada para pengusaha.

Upah menurut Afzalur, (2011)adalah harga dari tenaga yang dibayar atas jasanya dalam produksi. Sedangkan menurut Anto (2013) upah adalah kompensasi atas jasa yang diberiakan seorang tenaga kerja.Dan upah menurut UU kecelakaan tahun 1974 No. 33 Pasal 7 ayat (a) dimaksudkan adalah tiap-tiap pembayaran berupa uang yang diterima oleh buruh sebagai ganti pekerjaan.

\section{Biaya}

Pengertian biaya telah mengalami perkembangan, sekarang biaya ditentukan oleh nilai yang dikorbankan untuk mencapai sasaran sedangkan sebelumnya biaya diartikan sebagai seluruh pengeluaran yang dikeluarkan oleh perusahaan. Istilah biaya mempunyai arti yang sangat luas, karena adanya perbedaan tujuan biaya maka pengertian biaya juga berbeda pula. Biaya yang didefenisikan oleh Hansen, (2013)adalah kas atau nilai setara kas yang dikorbankan untuk mendapatkan barang atau jasa yang diharapkan dapat memberi manfaat saat ini atau dimasa yang akan datang bagi organisasi.
Menurut Horngen, (2009) biaya (cost) adalah sebagian sumber daya yang dikorbankan atau dilepaskan untuk mencapai tujuan tertentu. Suatu biaya diukur dengan jumlah uang yang harus dibayarkan dalam rangka mendapatkan barang atau jasa. Menurut Carter, (2004)biaya merupakan suatu nilai tukar prasyarat atau pengorbanan yang dilakukan guna memperoleh manfaat. Menurut Bustami \& Nurlela, (2010)Biaya adalah pengorbanan sumber ekonomi yang diukur dalam satuan uang yang telah terjadi atau kemungkinan akan terjadi untuk mencapai tujuan tertentu. Biaya ini belum habis masa pakainya dan digolongkan sebagai aktiva yang dimasukkan kedalam neraca.

\section{Output}

Proses dalam input produksi menghasilkan output. Komponen-komponen dalam output produksi dalam penelitian ini adalah jumlah produksi dan pendapatan.

\section{Jumlah Produksi}

Pengertian produksi lainnya yaitu hasil akhir dari proses atau aktivitas ekonomi dengan memanfaatkan beberapa masukan atau input. Dengan pengertian ini dapat dipahami bahwa kegiatan produksi diartikan sebagai aktivitas dalam menghasilkan output dengan menggunakan teknik produksi tertentu untuk mengolah atau memproses input sedemikian rupa (Sukirno, 2012).

\section{Pendapatan}

Pendapatan merupakan suatu hasil yang diterima oleh seseorang atau rumah tangga dari berusaha atau bekerja. Jenis masyarakat bermacam ragam, seperti bertani, nelayan, beternak, buruh, serta berdagang dan juga bekerja pada sektor pemerintah dan swasta (Pertiwi, 2015)

Pada konsep ekonomi, menurut Adam Smith penghasilan adalah jumlah yang dapat dikonsumsi tanpa harus mengakibatkan penurunan modal, termasuk modal tetap (fixed capital) dan modal berputar (circulating capital). Hicks mengatakan bahwa penghasilan adalah jumlah yang dikonsumsi oleh seseorang selama jangka waktu tertentu. Sementara itu, Henry C Simon 
yang memandang dari sudut penghasilan perorangan, mendefenisikan penghasilan sebagai jumlah dari nilai pasar barang dan jasa yang dikonsumsi dan perubahan nilai kekayaan yang ada pada awal dan akhir satu periode (Hafidoh, 2015).

\section{Efisiensi}

Hanafie, (2010)menyatakan bahwa efisiensi ialah usaha penggunaan input yang seminimum mungkin untuk memperoleh hasil produksi yang semaksimal mungkin. Simanjuntak dan Mukhlis (2012) berpendapat bahwa efisiensi yang direncanakan, dengan cara produksi dengan biaya murah, tetapi dengan tetap sesuai harapan, baik mutu dan barang yang diproduksi maupun pelayanannya. Selain itu efisiensi mencakup alokasi sumber daya, perilaku manusia, dan sistem kemasyarakatan namun efisiensi tidak harus berarti penghematan material saja, tetapi diperhitungkan pula aspek yang non-material (Murniati, 2004).

Dari uraian diatas dapat disimpulkan bahwasannya efisiensi adalah suatu cara atau usaha yang dilakukan dalam menjalankan sesuatu dengan baik dan tepat serta meminimalisir pemborosan dalam material maupun non material seperti waktu.

\section{Metode Data Envelopment Analysis (DEA)}

Metode Data Envelopment Analysis (DEA) mulai dikembangkan pada penelitian Farrell pada tahun 1957. Pada tahun 1958, Charnes, Cooper dan Rhodes menciptakan penggunaan model CCR untuk memperhitungkan Constant Return To Scale (CRS) dan pada tahun 1984, Banker ,Charnes dan Chooper memodifikasi metode DEA untuk kasus dimana kita tidak perlu mengoperasikan dengan parameter optimum. DEA adalah suatu non parametrik, metode optimisasi matematis yang digunakan untuk menghitung teknis, semata-mata teknis dan skala efisiensi untuk Decision Making Units (DMUs). (Mihai \& Dona, 2014)

$$
\text { Muharam \& Pusvitasari }
$$

menjelaskan DEA adalah sebuah metode optimasi program matematika yang mengukur efisiensi teknik suatu unit kegiatan ekonomi (UKE)/Decision Making Unit (DMU) dan membandingkan secara relatif terhadap DMU yang lain. Terdapat dua model pengukuran yang sering digunakan dalam pendekatan DEA Zhu dan Cook dalam(Hidayah, 2014) yaitu:

a) Charnes-Cooper-Rhodes (CCR) Model ini mengasumsikan adanya Constant Return to Scale (CRS), yaitu rasio antara penambahan input dan output adalah sama. Hal ini berarti, apabila ada tambahan sebesar $1 \%$ maka output akan meningkat sebesar 1\% juga. Asumsi lain dari model ini adalah setiap DMU beroperasi pada skala optimal.

b) Bankers-Charnes-Cooper Model ini dikembangkan oleh Bankers-CharnesCooper (BCC) ini merupakan pengembangan dari model CCR. Model ini mengasumsikan adanya Variable Return to Scale (VRS). Model ini beranggapan bahwa perusahaan belum beroperasi pada skala yang optimal. Asumsi dari model ini adalah bahwa rasio antara penambahan input dan output tidak sama. Artinya, penambahan input sebesar $1 \%$ tidak akan menyebabkan perubahan output sebesar $1 \%$ pula, namun bisa jadi lebih besar atau lebih kecil.

\section{Kerangka Konseptual}

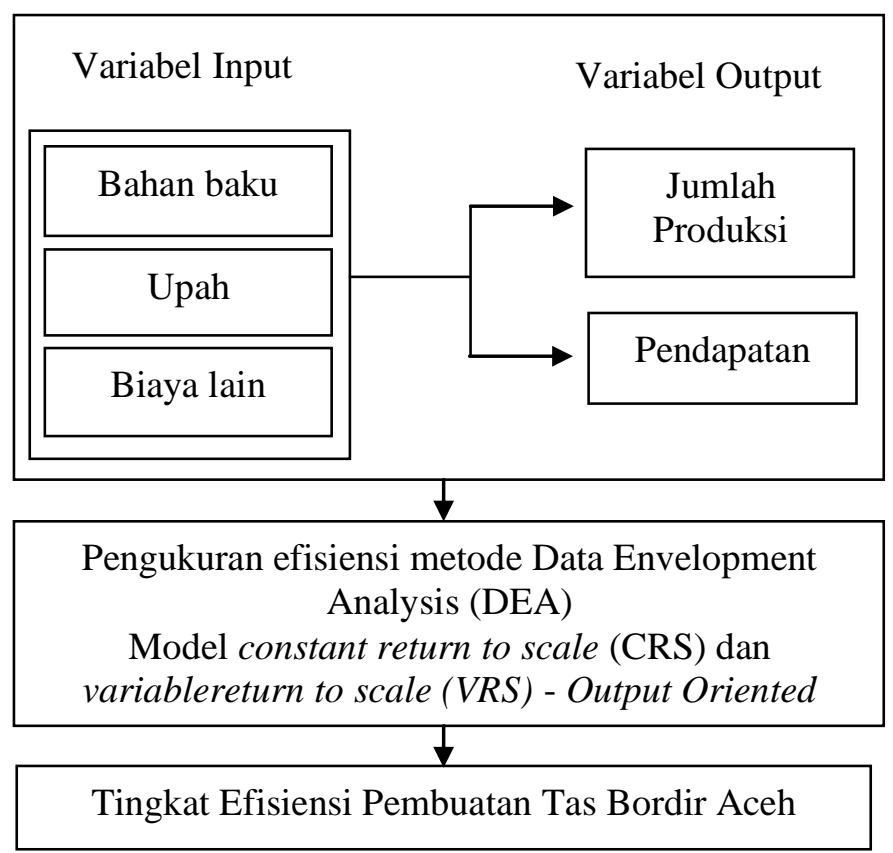

Gambar 1

Hipotesis
Kerangka Konseptual 
Hipotesis merupakan pandapat sementara dan pedoman serta arah dalam penelitian yang disusun berdasarkan pada teori yang terkait, dimana suatu hipotesis selalu dirumuskan dalam bentuk pernyataan yang menghubungkan dua variabel atau lebih (Supranto, 2011).

$\mathrm{H}_{0}$ : Diduga penggunaan input terhadap output pada usaha pembuatan tas bordir Aceh tidakefisiensi.

$\mathrm{H}_{1}$ : Diduga penggunaan input terhadap output pada usaha pembuatan tas bordir Aceh efisiensi.

\section{METODE PENELITIAN}

\section{Jenis dan Sumber Data}

Data didalam penelitian ini merupakan data primer dari 20unit usaha pembuatan tas bordir Aceh yang ada di Desa Ulee Madon Kecamatan Muara Batu Kabupaten Aceh Utara dengan variabel inputadalah Bahan baku, Upah, dan Biaya Lain dan variabel ouput adalahJumlah Produksi danPendapatan berbentuk data tahunan yang telah diakumulasi dari bulan februari 2018 hingga januari 2019. Sedangkan sumber data dalam penelitian ini berasal dari observasi peneliti langsung.

\section{Operasional Variabel Penelitian}

Bentuk Operasionalisasi dari variabelvariabel yang digunakan dalam penelitian ini dijabarkan sebagai berikut:

1. Variabel Output

1) Jumlah Produksi (Unit)

Jumlah produksi adalah total keseluruhan dari hasil produksi yang dihasilkan oleh usaha dalam suatu waktu tertentu.

2) Pendapatan (Rupiah)

Pendapatan merupakan suatu hasil yang diterima oleh seseorang atau rumah tangga dari berusaha atau bekerja.

2. Variabel Input

1) Bahan baku (Rupiah) barang-barang yang akan menjadi bagian dari produk jadi yang dengan mudah dapat diikuti biayanya.

2) Upah (Rupiah)

Harga dari tenaga yang dibayar atas jasanya dalam produksi.
3) Biaya Lain (Rupiah)

Biaya yang dikeluarkan diluar biaya tetap.

\section{Metode Analisis Data}

Dalam penelitian ini menggunakan metode analisis Data Envelopment Analisis (DEA) sebagai berikut:

Data Envelopment Analisis (DEA) merupakan metodelogi non-parametrik yang didasarkan pada linear programming. Data Envelopment Analysis (DEA) pada awalnya diperkenalkan oleh Farell pada tahun 1957 dengan dasar teori produksi mengukur efisiensi pada kinerja namun saat ini metode DEA bisa diterapkan pada berbagai disiplin ilmu terlebih dalam ilmu sosial ekonomi sehingga mempermudah para pembuatan kebijakan dalam mengambil keputusan.

Menurut (Blackburn and Zhu n.d.) data Envelopment Analysis (DEA) adalah istilah yang diciptakan dalam literatur operasi penelitian oleh Chares, Cooper, dan Rhodes pada tahun 1978 untukmengukur decision making units (DMUs) dengan asumsi skala hasil konstan beberapa masukan, beberapa output korespondensi. Kemudian model DEA dikembangkan lagi oleh Banker, Charnes, dan Cooper pada tahun 1984.Untuk memungkinkan variabel kembali ke skala dan menunjukan bahwa solusi untuk kembali konstan untuk skala dan variabel ke skala modal menunjukan dekomposisi menjadi komponen teknis dan skala.

Dalam penelitian ini menggunakan metode Data Envelopment Analysis (DEA) yang terdapat dua Model yaitu Constant Retrun to Scale (CRS) dan model Model Variabel Retrun to Scale (VRS).

\section{Model Constant Retrun to Scale (CRS)output oriented}

Merupakan model yang dikembangkan oleh Cooper, Charnes, dan Rhodes pada tahun 1978, CRS juga dikenal juga dengan model CCR yang mengukur efisiensi menggunakan asumsi constan return to scale yang membawa implikasi pada bentuk efisien set linear. Pada model ini berasumsi bahwa rasio penambahan input dan output adalah sama (constant return to scale), dimana jika 
penambahan satu input sebesar $n$ kali, maka output juga akan bertambah sebesar $n$ kali. Pada model ini dijelasakan suatu ukuran efisiensi untuk masing-masing decision making unit (DMU) yang merupakan rasio maksimum antara output yang berbobot dengan output yang berbobot. Masingmasing nilai bobot yang digunakan dalam rasio tersebut ditentukan dengan batasan bahwa rasio yang sama untuk tiap DMU harus memiliki nilai yang kurang dari atau sama dengan satu. CRSoutput oriented model ini bertujuan memaksimalkan tingkat ouput dari penggunaan input.

Model persamaan pada CRS dapat dituliskan sebagai berikut:

$$
\begin{array}{ll}
\text { maximize } \Omega_{0} & \\
\text { subject to } & -X_{0 i}+\sum_{k=1}^{s} X_{k} \lambda_{k} \leq 0, \quad i=\quad 1,2, \ldots, n, \\
& -Y_{0,} \Omega_{0}+\sum_{k=1}^{S} Y_{k} \lambda_{k} \geq 0, \quad j=1,2, \ldots, m, \\
& \lambda_{k} \geq 0, \quad k=1,2, \ldots, S,
\end{array}
$$

\section{Model Variabel Retrun to Scale (VRS)-output} oriented

Model Variabel Retrun to Scale (VRS) dikembangkan oleh Banker, Charnes, dan Cooper pada tahun 1984. Mengikuti metodologi yang seperti "input" dan "output" sebagian besar generik. Kinerja yang tidak diinginkan atribut dianggap input dan kinerja atribut yang diinginkan (seperti pertumbuhan ekonomi) dianggap output.

Metode VRS adalah kebalikan dan metode CRS yaitu tidak ada hubungan linear antara input dan output. Setiap penambahan input tidak menghasilkan ouput yang proporsionalnya sehingga sehingga efisiensinya bisa saja naik atau turun VRS-output oriented model ini bertujuan memaksimalkan tingkat ouput dari penggunaan input.

Model persamaanya adalah sebagai berikut:

$$
\begin{aligned}
& \underset{\operatorname{maximize}}{\operatorname{subject} \text { to }} \\
& -X_{0 i}+\sum_{k=1}^{S} X_{k i} \lambda_{k} \leq 0, \quad i=1,2, \ldots, n, \\
& -Y_{0 j} \Omega_{0}+\sum_{k=1}^{S} Y_{k j} \lambda_{k} \geq 0, \quad j=1,2, \ldots, m, \\
& \sum_{k=1}^{S} \lambda_{k}=1 . \\
& \lambda_{k} \geq 0, \quad k=1,2, \ldots, S,
\end{aligned}
$$

Dimana

$\Omega 0=$ Efisiensi DMU pada CRS

$\mathrm{N}=$ jumlah DMU

$\mathrm{M}=$ jumlah input

$\mathrm{S}=$ jumlah output

Xkí = jumlah input ke-i DMU j

$Y k j=$ jumlah input ke-i DMU j

$\chi_{\mathrm{k}}=$ bobot DMU $\mathrm{j}$ untuk DMU yang dihitung

\section{HASIL PENELITIAN DAN PEMBAHASAN}

\section{Hasil Penelitian}

Berdasarkan hasil pengolahan data dengan menggunakan metode DEA model CRS dan VRS yang berorientasikan pada output pada software DEAP versi 2.1 untuk menganalisis nilai efisiensi pembuatan Tas Border Aceh di Gampong Ulee Madon diperoleh hasil sebagai berikut.

Tabel 2

Hasil Perhitungan Technical Efficiency DEA Pada Usaha Pembuatan Tas Bordir Aceh di Gampong Ulee Madon dengan Pendekatan CRS dan VRS dengan Orientasi Output

\begin{tabular}{|c|l|r|r|}
\hline \multirow{2}{*}{ DMU } & \multirow{2}{*}{ Nama Pemilik } & \multicolumn{2}{|c|}{ Nilai Efisiensi } \\
\cline { 3 - 4 } & & CRS & VRS \\
\hline 1 & Nyak Cut & 1,000 & 1.000 \\
\hline 2 & Maryana & 0,782 & 1.000 \\
\hline 3 & Jarjani & 0,938 & 0.925 \\
\hline 4 & Tabina & 1,000 & 0.972 \\
\hline 5 & Nadia & 0,991 & 1.000 \\
\hline 6 & Nurjani & 0,812 & 1.000 \\
\hline 7 & Marzuki & 0,855 & 0.917 \\
\hline 8 & Sanusi & 0,938 & 0.938 \\
\hline 9 & Bungong Rauza & 0,885 & 0.958 \\
\hline 10 & Jailani & 0,709 & 0.882 \\
\hline 11 & Nuria & 0,925 & 0.939 \\
\hline 12 & Putrona & 0,836 & 0.957 \\
\hline 13 & Pelita & 0,869 & 0.909 \\
\hline 14 & Pelita Sri Maryati & 0,934 & 0.974 \\
\hline 15 & Sanyo Bag & 0,945 & 0.993 \\
\hline 16 & Naiart Cop Tah & 0,838 & 0.971 \\
\hline 17 & Nisa & 1,000 & 1.000 \\
\hline 18 & Rolan & 0,909 & 0.948 \\
\hline 19 & Zaini & 1,000 & 1.000 \\
\hline 20 & Anwar & $\mathbf{0 , 9 0 2}$ & $\mathbf{0 . 9 6 4}$ \\
\hline Mean & & & \\
\hline Sung
\end{tabular}

Sumber: Hasil olah data, 2019 
Berdasarkan dari hasil pengujian dengan menggunakan aplikasi DEAP versi 2.1 pada tabel 2 di atas dapat dilihat bahwa pengujian dengan model CRS yang berorientasi pada output hanya 4 DMU atau pemilik usaha tas bordir Aceh yang memperoleh nilai efisiensi sama dengan satu $(=1)$. Hal ini berarti bahwa keempat pemilik usaha tas bordir Aceh tersebut yaitu Maryana, Nadia, Rolan, Anwartelah mengefisienkan penggunaan input untuk menghasilkan output yang maksimal. Sedangkan 13 pemilik usaha peembuatan tas bordir Aceh lainnya belum mengefisienkan penggunaan input untuk menghasilkan output yang lebih maksimal.

Pengukuran yang dilakukan dengan menggunakan model VRS yang berorientasi pada output menunjukkan bahwa terdapat 7 usaha pembuatan tas bordir Aceh yaitu usaha milik Nyak Cut, Maryana, Nadia, Nurjani, Bungong Rauza, Nisa, dan Anwaryang memperoleh nilai efisiensi sama dengan satu (=1), yang berarti bahwa telah mengefisienkan output yang dihasilkan. Sedangkan 13 usaha pembuatan tas bordir Aceh lainnya memperoleh nilai efisiensi kurang dari satu (<1) atau belum efisien. Dari dua model pengukuran tersebut diketahui bahwa terdapat lebih banyak usaha pembuatan tas bordir Aceh yang efisien dengan model VRS.

\section{Pembahasan}

Pada bagian ini memuat pembahasan mengenai tingkat efisiensi dan inefisiensi yang dilihat dari penggunaan input dan hasil output pada usaha pembuatan tas bordir Aceh di Desa Ulee Madon Kecamatan Muara Batu Kabupaten Aceh utara berdasarkan hasil perhitungan efisiensi DEA pendekatan CRSdan VRS yang berorientasi padaoutput.

\section{Tingkat Efesiensi Usaha Pembuatan Tas Bordir Aceh dengan Menggunakan Pendekatan CRS- Output Oriented}

\section{Nyak Cut}

Tabel 3

Nilai Original, Target, Radial Movement dan Slack Movement Input Output Usaha Tas Bordir Aceh Nyak Cut yang Inefisiensi

\begin{tabular}{|c|c|c|c|c|c|}
\hline Variabel & $\begin{array}{c}\text { Nilai } \\
\text { Efisiensi }\end{array}$ & $\begin{array}{c}\text { Original } \\
\text { Value }\end{array}$ & Target Value & $\begin{array}{c}\text { Radial } \\
\text { Movement }\end{array}$ & $\begin{array}{c}\text { Slack } \\
\text { Movement }\end{array}$ \\
\hline 2018-2019 & $\mathbf{0 , 8 7 6}$ & 127.500 .000 & $145.570 .405,18$ & $18.070 .405,18$ & 0.000 \\
\hline putput & Pendapat & 120 & \\
\hline
\end{tabular}

\begin{tabular}{|l|l|r|r|r|r|}
\cline { 2 - 6 } & \multicolumn{1}{c|}{ an } & & & & \\
\cline { 2 - 6 } & $\begin{array}{l}\text { Jumlah } \\
\text { Produksi }\end{array}$ & 510 & 582,28 & 72.282 & 0.000 \\
\hline \multirow{3}{*}{ nput } & $\begin{array}{l}\text { Bahan } \\
\text { Baku }\end{array}$ & 23.080 .000 & 23.080 .000 & 0.000 & 0.000 \\
\cline { 2 - 6 } & Upah & 38.000 .000 & 38.000 .000 & 0.000 & 0.000 \\
\cline { 2 - 6 } & $\begin{array}{l}\text { Biaya- } \\
\text { biaya lain }\end{array}$ & 10.800 .000 & 10.800 .000 & 0.000 & 0.000 \\
\hline
\end{tabular}

Sumber: Hasil Olah Data (2019)

Pada tabel 4.4 di atas dapat dilihat bahwa berdasarkan pengukuran efisiensi model CRS yang berorientasi pada output usaha Nyak Cut memperoleh nilai skala efisiensi sebesar 0,876 yang berarti bahwa mengalami inefisiensi. Maka untuk meningkatkan nilai skala efisien menjadi satu (1) harus ditingkatkan sebesar $1-0,876=$ 0,124 . Usaha pembuatan tas bordir Aceh milik Nyak Cut mengalami inefisiensi pada output kedua output yaitu pendapatan dan jumlah produksi. Adapun upaya yang dapat dilakukan oleh Nyak Cut adalah sebagai berikut.

Pada output pendapatan terlihat bahwa dengan input yang telah digunakan Nyak Cut memperoleh hasil sebesar Rp127.500.000, sementara itu di target value (nilai target) yang harus dihasilkan oleh usaha Nyak Cut untuk output pendapatan adalah sebesar Rp 145.570.405,18. Oleh karenanya untuk meningkatkan nilai skala efisiensi usahanya, Nyak Cut harus meningkatkan pendapatannya sebesar $\mathrm{Rp} \quad 145.570 .405,18$ - $\mathrm{Rp} 127.500 .000=\mathrm{Rp}$ 18.070.405,18, hal ini juga dapat dilihat pada besaran radial movement.

Sedangkan pada output jumlah produksi, usaha Nyak Cut telah menghasilkan sejumlah 510 unit, padahal usaha pembuatan tas bordir Aceh Nyak Cut masih dapat memaksimalkan jumlah produksi sebesar nilai target yaitu 582 unit. Maka untuk meningkatkan nilai skala efisiensi usaha pembuatan tas bordir Aceh Nyak Cut dapat meningkatkan jumlah produksinya sebesar radial movement yaitu 72 unit dari jumlah produksi yang telah dihasilkan guna mengefisienkan atau meningkatan nilai skala efisiensi usaha pembuatan tas bordir Aceh dengan slack movement sebesar $\operatorname{Rp} 0$. 


\section{Jarjani}

Tabel 4

Nilai Original, Target, Radial Movement dan Slack Movement Input Output Usaha Tas Bordir Aceh Jarjani yang Inefisiensi

\begin{tabular}{|c|c|c|c|c|c|}
\hline Variabel & $\begin{array}{l}\text { Nilai } \\
\text { Efisiensi }\end{array}$ & \multirow{2}{*}{$\begin{array}{l}\text { Original } \\
\text { Value }\end{array}$} & \multirow{2}{*}{ Target Value } & \multirow{2}{*}{$\begin{array}{l}\text { Radial } \\
\text { Movement }\end{array}$} & \multirow{2}{*}{$\begin{array}{l}\text { Slack } \\
\text { Movement }\end{array}$} \\
\hline $\begin{array}{l}2018- \\
2019\end{array}$ & 0,782 & & & & \\
\hline \multirow[t]{2}{*}{ utput } & Pendapatan & 118.000 .000 & $150.911 .261,58$ & $32.911 .261,58$ & 0.000 \\
\hline & $\begin{array}{l}\text { Jumlah } \\
\text { Produksi }\end{array}$ & 472 & 603,65 & 131,65 & 0.000 \\
\hline \multirow[t]{3}{*}{ nput } & $\begin{array}{l}\text { Bahan } \\
\text { Baku }\end{array}$ & 23.220 .000 & 23.220 .000 & 0.000 & 0.000 \\
\hline & Upah & 54.000 .000 & 41.277 .263 & 0.000 & $\overline{1}-\overline{722.736,99}$ \\
\hline & $\begin{array}{l}\text { Biaya- } \\
\text { biaya lain }\end{array}$ & 12.000 .000 & 12.000 .000 & 0.000 & 0.000 \\
\hline
\end{tabular}

Sumber: Hasil Olah Data (2019)

Pada tabel 4.5 di atas dapat dilihat bahwa berdasarkan pengukuran efisiensi model CRS yang berorientasi pada output usaha Jarjani memperoleh nilai skala efisiensi sebesar 0,782yang berarti mengalami inefisiensi. Maka untuk meningkatkan nilai skala efisien menjadi satu (1) harus ditingkatkan sebesar $1-0,782=0,218$. Usaha pembuatan tas bordir Aceh milik Jarjani mengalami inefisiensi pada kedua output yaitu pendapatan dan jumlah produksi. Adapun upaya yang dapat dilakukan oleh Jarjani adalah sebagai berikut.

Pada output pendapatan terlihat bahwa dengan input yang telah digunakan Jarjani memperoleh hasil sebesar Rp 118.000.000, sementara itu di target value (nilai target) yang harus dihasilkan oleh usaha Jarjani untuk output pendapatan adalah sebesar Rp 150.911.261,58. Oleh karenanya untuk meningkatkan nilai skala efisiensi usahanya, Jarjani harus meningkatkan pendapatannya sebesar Rp 118.000.000 - Rp 150.911.261,58 = Rp 32.911.261,58, hal ini juga dapat dilihat pada besaran radial movement .

Sedangkan pada output jumlah produksi, usaha Jarjani telah menghasilkan sejumlah 472 unit, padahal usaha pembuatan tas bordir Aceh Jarjani masih dapat memaksimalkan jumlah produksi sebesar nilai target yaitu 604 unit. Maka untuk meningkatkan nilai skala efisiensi usaha pembuatan tas bordir Aceh Jarjani dapat meningkatkan jumlah produksinya sebesar radial movement yaitu 132 unit dari jumlah produksi yang telah dihasilkan guna mengefisienkan atau meningkatan nilai skala efisiensi usaha pembuatan tas bordir Aceh dengan slack movement sebesar Rp 0.
Pada, usaha pembuatan tas bordir Aceh milik Jarjani bernilai target sebesar Rp 41.277.263 maka untuk lebih mengefisienkan usaha pembuatan tas bordir Aceh nya Jarnaji dapat mengurangi pengeluaran pada upah sebesar $\mathrm{Rp}$ 54.000.000 - Rp41.277.263 = Rp 12.722.736,99. Hal in juga dapat dilihat pada besaran nilai slack movement.

\section{Tabina}

Tabel 5

Nilai Original, Target, Radial Movement dan Slack Movement Input Output Usaha Tas Bordir Aceh Tabina yang Inefisiensi

\begin{tabular}{|c|c|c|c|c|c|}
\hline Variabel & $\begin{array}{l}\text { Nilai } \\
\text { Efisiensi }\end{array}$ & \multirow{2}{*}{$\begin{array}{l}\text { Original } \\
\text { Value }\end{array}$} & \multirow{2}{*}{ Target Value } & \multirow{2}{*}{$\begin{array}{l}\text { Radial } \\
\text { Movement }\end{array}$} & \multirow{2}{*}{$\begin{array}{l}\text { Slack } \\
\text { Movement }\end{array}$} \\
\hline $\begin{array}{l}2018- \\
2019\end{array}$ & 0,938 & & & & \\
\hline \multirow{2}{*}{ putput } & Pendapatan & 122.250 .000 & $130.369 .821,14$ & $8.119 .821,14$ & 0.000 \\
\hline & $\begin{array}{l}\text { Jumlah } \\
\text { Produksi }\end{array}$ & 489 & 521,48 & 32,48 & 0.000 \\
\hline \multirow[t]{3}{*}{ nput } & Bahan Baku & 19.770 .000 & 19.770 .000 & 0.000 & 0.000 \\
\hline & Upah & 36.000 .000 & 36.000 .000 & 0.000 & 0.000 \\
\hline & $\begin{array}{l}\text { Biaya-biaya } \\
\text { lain }\end{array}$ & 10.800 .000 & 10.800 .000 & 0.000 & 0.000 \\
\hline
\end{tabular}

Sumber: Hasil Olah Data (2019)

Pada tabel 5 di atas dapat dilihat bahwa berdasarkan pengukuran efisiensi model CRS yang berorientasi pada output usaha Tabina memperoleh nilai skala efisiensi sebesar 0,938yang berarti mengalami inefisiensi. Maka untuk meningkatkan nilai skala efisien menjadi satu (=1) harus ditingkatkan sebesar 1-0,938= 0,062 . Usaha pembuatan tas bordir Aceh milik Tabina mengalami inefisiensi pada kedua output yaitu pendapatan dan jumlah produksi. Adapun upaya yang dapat dilakukan oleh Tabina adalah sebagai berikut.

Pada output pendapatan terlihat bahwa dengan input yang telah digunakan Tabina memperoleh hasil sebesar Rp 122.250.000, sementara itu di target value (nilai target) yang harus dihasilkan oleh usaha Tabina untuk output pendapatan adalah sebesar $\mathrm{Rp}$ 130.369.821,14. Oleh karenanya untuk meningkatkan nilai skala efisiensi usahanya, Tabina harus meningkatkan pendapatannya sebesar Rp 122.250.000 - Rp $130.369 .821,14=\operatorname{Rp} 8.119 .821,14$, hal ini juga dapat dilihat pada besaran radial movement .Sedangkan pada output jumlah produksi, usaha Tabina telah menghasilkan sejumlah 489unit, padahal usaha pembuatan tas bordir Aceh Tabina masih dapat memaksimalkan jumlah produksi sebesar nilai target yaitu 522 unit. Maka untuk meningkatkan nilai skala efisiensi usaha 
pembuatan tas bordir Aceh Tabina dapat meningkatkan jumlah produksinya sebesar radial movement yaitu 33 unit dari jumlah produksi yang telah dihasilkan guna mengefisienkan atau meningkatan nilai skala efisiensi usaha pembuatan tas bordir Aceh dengan slack movement sebesar Rp 0.

\section{Nurjani}

Tabel 6

Nilai Original, Target, Radial Movement dan Slack Movement Input Output Usaha Tas Bordir Aceh Nurjani Yang Inefisiensi Dengan Tingkat EfisiensiZ

\begin{tabular}{|c|c|c|c|c|c|}
\hline Variabel & $\begin{array}{l}\text { Nilai } \\
\text { Efisiensi }\end{array}$ & \multirow{2}{*}{$\begin{array}{l}\text { Original } \\
\text { Value }\end{array}$} & \multirow[t]{2}{*}{ Target Value } & \multirow{2}{*}{$\begin{array}{l}\text { Radial } \\
\text { Movement }\end{array}$} & \multirow{2}{*}{$\begin{array}{l}\text { Slack } \\
\text { Movement }\end{array}$} \\
\hline 2018-2019 & 0,991 & & & & \\
\hline \multirow{2}{*}{ Dutput } & Pendapatan & 124.750 .000 & $125.871 .737,54$ & $1.121 .737,543$ & 0.000 \\
\hline & $\begin{array}{l}\text { Jumlah } \\
\text { Produksi }\end{array}$ & 499 & 503,49 & 4,487 & 0.000 \\
\hline \multirow[t]{3}{*}{ nput } & $\begin{array}{l}\text { Bahan } \\
\text { Baku }\end{array}$ & 18.710 .000 & 18.710 .000 & 0.000 & 0.000 \\
\hline & Upah & 36.000 .000 & 36.000 .000 & 0.000 & 0.000 \\
\hline & $\begin{array}{l}\text { Biaya- } \\
\text { biaya lain }\end{array}$ & 10.800 .000 & 10.800 .000 & 0.000 & 0.000 \\
\hline
\end{tabular}

Sumber: Hasil Olah Data (2019)

Pada tabel 6 di atas dapat dilihat bahwa berdasarkan pengukuran efisiensi model CRS yang berorientasi pada output usaha Nurjani memperoleh nilai skala efisiensi sebesar 0,991 yang berarti mengalami inefisiensi. Maka untuk meningkatkan nilai skala efisien menjadi satu (1) harus ditingkatkan sebesar 1-0,991 $=0,009$. Usaha pembuatan tas bordir Aceh milik Nurjani mengalami inefisiensi pada kedua output yaitu pendapatan dan jumlah produksi. Adapun upaya yang dapat dilakukan oleh Nurjani adalah sebagai berikut.

Pada output pendapatan terlihat bahwa dengan input yang telah digunakan Nurjani memperoleh hasil sebesar Rp 124.750.000, sementara itu di target value (nilai target) yang harus dihasilkan oleh usaha Nurjani untuk output pendapatan adalah sebesar Rp 125.871.737,54. Oleh karenanya untuk meningkatkan nilai skala efisiensi usahanya, Nurjani harus meningkatkan pendapatannya sebesar Rp 124.750.000 - Rp $125.871 .737,54=\operatorname{Rp} 1.121 .737,543$, hal ini juga dapat dilihat pada besaran radial movement.

Sedangkan pada output jumlah produksi, usaha Jarjani telah menghasilkan sejumlah 499 unit, padahal usaha pembuatan tas bordir Aceh Nurjani masih dapat memaksimalkan jumlah produksi sebesar nilai target yaitu 504unit. Maka untuk meningkatkan nilai skala efisiensi usaha pembuatan tas bordir Aceh Nurjani harus meningkatkan jumlah produksinya sebesar radial movement yaitu 5 unit dari jumlah produksi yang telah dihasilkan guna mengefisienkan atau meningkatan nilai skala efisiensi usaha pembuatan tas bordir Aceh dengan slack movement sebesar Rp 0.

\section{Marzuki}

Tabel 7

Nilai Original, Target, Radial Movement dan Slack Movement Input Output Usaha Tas Bordir Aceh Marzuki yang Inefisiensi

\begin{tabular}{|l|l|l|l|l|l|}
\hline Variabel & $\begin{array}{l}\text { Nilai } \\
\text { Efisiensi }\end{array}$ & $\begin{array}{l}\text { Original } \\
\text { Value }\end{array}$ & Target Value & $\begin{array}{l}\text { Radial } \\
\text { Movement }\end{array}$ & $\begin{array}{l}\text { Slack } \\
\text { Movement }\end{array}$ \\
\hline 2018-2019 & $\mathbf{0 , 8 1 2}$ & 116.500 .000 & $143.482 .159,15$ & $26.982 .159,153$ & 0.000 \\
\hline Putput & Pendapatan & & 573,93 & 107,93 & 0.000 \\
\cline { 2 - 5 } & $\begin{array}{l}\text { Jumlah } \\
\text { Produksi }\end{array}$ & 466 & 22.860 .000 & 0.000 & 0.000 \\
\hline \multirow{3}{*}{ nput } & $\begin{array}{l}\text { Bahan } \\
\text { Baku }\end{array}$ & 22.860 .000 & 36.000 .000 & 0.000 & 0.000 \\
\cline { 2 - 5 } & Upah & 36.000 .000 & 10.800 .000 & 0.000 & 0.000 \\
\cline { 2 - 6 } & $\begin{array}{l}\text { Biaya- } \\
\text { biaya lain }\end{array}$ & 10.800 .000 & & & \\
\hline
\end{tabular}

Sumber: Hasil Olah Data (2019)

Pada tabel 7 di atas dapat dilihat bahwa berdasarkan pengukuran efisiensi model CRS yang berorientasi pada output usaha Marzuki memperoleh nilai skala efisiensi sebesar 0,812 yang berarti mengalami inefisiensi. Maka untuk meningkatkan nilai skala efisien menjadi satu (1) harus ditingkatkan sebesar 1-0,812=0,188. Usaha pembuatan tas bordir Aceh milik Marzuki mengalami inefisiensi pada kedua output yaitu pendapatan dan jumlah produksi. Adapun upaya yang dapat dilakukan oleh Marzuki adalah sebagai berikut.

Pada output pendapatan terlihat bahwa dengan input yang telah digunakan Marzuki memperoleh hasil sebesar Rp 116.500.000, sementara itu di target value (nilai target) yang harus dihasilkan oleh usaha Marzuki untuk output pendapatan adalah sebesar Rp 143.482.159,15. Oleh karenanya untuk meningkatkan nilai skala efisiensi usahanya, Marzuki harus meningkatkan pendapatannya sebesar Rp 116.500 .000 - Rp 143.482.159,15= Rp 26.982.159,15, hal ini juga dapat dilihat pada besaran radial movement.

Sedangkan pada output jumlah produksi, usaha Marzuki telah menghasilkan sejumlah 466 unit, padahal usaha pembuatan tas bordir Aceh Marzuki masih dapat memaksimalkan jumlah produksi sebesar nilai target yaitu 574unit. Maka untuk meningkatkan nilai skala efisiensi usaha pembuatan tas bordir Aceh Marzuki harus 
meningkatkan jumlah produksinya sebesar radial movement yaitu 108 unit dari jumlah produksi yang telah dihasilkan guna mengefisienkan atau meningkatan nilai skala efisiensi usaha pembuatan tas bordir Aceh dengan slack movement sebesar Rp 0.

\section{Sanusi}

\section{Tabel 8}

Nilai Original, Target, Radial Movement dan Slack Movement Input Output Usaha Tas Bordir Aceh Sanusi yang Inefisiensi

\begin{tabular}{|l|l|l|l|l|l|}
\hline Variabel & $\begin{array}{l}\text { Nilai } \\
\text { Efisiensi }\end{array}$ & $\begin{array}{l}\text { Original } \\
\text { Value }\end{array}$ & Target Value & $\begin{array}{l}\text { Radial } \\
\text { Movement }\end{array}$ & $\begin{array}{l}\text { Slack } \\
\text { Movement }\end{array}$ \\
\hline $\begin{array}{l}\mathbf{2 0 1 8 -} \\
\mathbf{2 0 1 9}\end{array}$ & $\mathbf{0 , 8 5 5}$ & 119.000 .000 & $139.236 .279,40$ & $20.236 .279,401$ & 0.000 \\
\hline putput & Pendapatan & 176 & 556,95 & 80,95 & 0.000 \\
\cline { 2 - 6 } & $\begin{array}{l}\text { Jumlah } \\
\text { Produksi }\end{array}$ & 476 & 0.000 & 0.000 \\
\hline \multirow{3}{*}{ nput } & $\begin{array}{l}\text { Bahan } \\
\text { Baku }\end{array}$ & 20.620 .000 & 20620000 & 0.000 & - \\
\cline { 2 - 5 } & Upah & 48.000 .000 & $40.165 .359,94$ & $7.834 .640,057$ \\
\cline { 2 - 5 } & $\begin{array}{l}\text { Biaya- } \\
\text { biaya lain }\end{array}$ & 12.000 .000 & 12.000 .000 & 0.000 & 0.000 \\
\hline
\end{tabular}

Sumber: Hasil Olah Data (2019)

Pada tabel 8 di atas dapat dilihat bahwa berdasarkan pengukuran efisiensi model CRS yang berorientasi pada output usaha Sanusi memperoleh nilai skala efisiensi sebesar 0,855 yang berarti mengalami inefisiensi. Maka untuk meningkatkan nilai skala efisien menjadi satu (1) harus ditingkatkan sebesar $1-0,855=0,145$. Usaha pembuatan tas bordir Aceh milik Sanusi mengalami inefisiensi pada kedua output yaitu pendapatan dan jumlah produksi. Adapun upaya yang dapat dilakukan oleh Sanusi adalah sebagai berikut.

Pada output pendapatan terlihat bahwa dengan input yang telah digunakan Sanusi memperoleh hasil sebesar Rp 119.000.000, sementara itu di target value (nilai target) yang harus dihasilkan oleh usaha Sanusi untuk output pendapatan adalah sebesar Rp 139.236.279,40. Oleh karenanya untuk meningkatkan nilai skala efisiensi usahanya, Sanusi harus meningkatkan pendapatannya sebesar Rp119.000.000 - Rp 139.236.279,40= Rp 20.236.279,40.Hal ini juga dapat dilihat pada besaran radial movement.

Sedangkan pada output jumlah produksi, usaha Sanusi telah menghasilkan sejumlah 476unit, padahal usaha pembuatan tas bordir Aceh Sanusi masih dapat memaksimalkan jumlah produksi sebesar nilai target yaitu 557unit. Maka untuk meningkatkan nilai skala efisiensi usaha pembuatan tas bordir Aceh Sanusi harus meningkatkan jumlah produksinya sebesar radial movement yaitu 81 unit dari jumlah produksi yang telah dihasilkan guna mengefisienkan atau meningkatan nilai skala efisiensi usaha pembuatan tas bordir Aceh dengan slack movement sebesar Rp 0.

Pada, usaha pembuatan tas bordir Aceh milik Sanusi bernilai target sebesar Rp 40.165.359,94 maka untuk lebih mengefisienkan usaha pembuatan tas bordir Aceh nya Sanusi dapat mengurangi pengeluaran pada upah sebesar Rp 48.000.000 - $\mathrm{Rp} 40.165 .359,94=\mathrm{Rp}$ 7.834.640,057. Hal ini juga dapat dilihat pada besaran nilai slack movement.

\section{Bungong Rauza}

Tabel 9

Nilai Original, Target, Radial Movement dan Slack Movement Input Output Usaha Tas Bordir Aceh Bungong Rauza yang Inefisiensi

\begin{tabular}{|c|c|c|c|c|c|}
\hline Variabel & $\begin{array}{l}\text { Nilai } \\
\text { Efisiensi } \\
\end{array}$ & \multirow{2}{*}{$\begin{array}{l}\text { Original } \\
\text { Value }\end{array}$} & \multirow{2}{*}{ Target Value } & \multirow{2}{*}{$\begin{array}{l}\text { Radial } \\
\text { Movement }\end{array}$} & \multirow{2}{*}{$\begin{array}{l}\text { Slack } \\
\text { Movement }\end{array}$} \\
\hline $\begin{array}{l}2018- \\
2019\end{array}$ & 0,938 & & & & \\
\hline \multirow[t]{2}{*}{ putput } & Pendapatan & 127.000 .000 & $135.326 .428,18$ & $8.326 .428,18$ & 0.000 \\
\hline & $\begin{array}{l}\text { Jumlah } \\
\text { Produksi }\end{array}$ & 508 & 541,31 & 33,31 & 0.000 \\
\hline \multirow[t]{3}{*}{ nput } & Bahan Baku & 20.802 .000 & 20.802 .000 & 0.000 & 0.000 \\
\hline & Upah & 37.000 .000 & 37.000 .000 & 0.000 & 0.000 \\
\hline & $\begin{array}{l}\text { Biaya-biaya } \\
\text { lain }\end{array}$ & 10.800 .000 & 10.800 .000 & 0.000 & 0.000 \\
\hline
\end{tabular}

Sumber: Hasil Olah Data (2019)

Pada tabel 9 di atas dapat dilihat bahwa berdasarkan pengukuran efisiensi model CRS yang berorientasi pada output usaha Sanusi memperoleh nilai skala efisiensi sebesar 0,938 yang berarti mengalami inefisiensi. Maka untuk meningkatkan nilai skala efisien menjadi satu (1) harus ditingkatkan sebesar 1-0,938 =0,062. Usaha pembuatan tas bordir Aceh milik Bungong Rauza mengalami inefisiensi pada output kedua output yaitu pendapatan dan jumlah produksi. Adapun upaya yang dapat dilakukan oleh Bungong Rauza adalah sebagai berikut.

Pada output pendapatan terlihat bahwa dengan input yang telah digunakan Bungong Rauza memperoleh hasil sebesar Rp 127.000.000, sementara itu di target value (nilai target) yang harus dihasilkan oleh usaha Bungong Rauza untuk output pendapatan adalah sebesar Rp 135.326.428,18. Oleh karenanya untuk meningkatkan nilai skala efisiensi usahanya, Bungong Rauza harus meningkatkan pendapatannya sebesar Rp127.000.000 - Rp 135.326.428,18= Rp 8.326.428,18.Hal ini juga dapat dilihat pada besaran nilai radial movement. 
Sedangkan pada output jumlah produksi, usaha Bungong Rauza telah menghasilkan sejumlah 508 unit, padahal usaha pembuatan tas bordir Aceh Bungong Rauza masih dapat memaksimalkan jumlah produksi sebesar nilai target yaitu 541unit. Maka untuk meningkatkan nilai skala efisiensi usaha pembuatan tas bordir Aceh Bungong Rauza harus meningkatkan jumlah produksinya sebesar radial movement yaitu 33 unit dari jumlah produksi yang telah dihasilkan guna mengefisienkan atau meningkatan nilai skala efisiensi usaha pembuatan tas bordir Aceh dengan slack movement sebesar Rp 0.

\section{Jailani}

\section{Tabel 10}

Nilai Original, Target, Radial Movement dan Slack Movement Input Output Usaha Tas Bordir AcehJailani Yang Inefisiensi

\begin{tabular}{|c|c|c|c|c|c|}
\hline Variabel & $\begin{array}{l}\text { Nilai } \\
\text { Efisiensi }\end{array}$ & \multirow{2}{*}{$\begin{array}{l}\text { Original } \\
\text { Value }\end{array}$} & \multirow[t]{2}{*}{ Target Value } & \multirow{2}{*}{$\begin{array}{l}\text { Radial } \\
\text { Movement }\end{array}$} & \multirow{2}{*}{$\begin{array}{l}\text { Slack } \\
\text { Movement }\end{array}$} \\
\hline 2018-2019 & 0,855 & & & & \\
\hline \multirow[t]{2}{*}{ Dutput } & Pendapatan & 120.250 .000 & $135.914 .239,85$ & $15.664 .239,85$ & 0.000 \\
\hline & $\begin{array}{l}\text { Jumlah } \\
\text { Produksi }\end{array}$ & 481 & 543,66 & 62,66 & 0.000 \\
\hline \multirow[t]{3}{*}{ nput } & $\begin{array}{l}\text { Bahan } \\
\text { Baku }\end{array}$ & 21.960 .000 & 21.960 .000 & 0.000 & 0.000 \\
\hline & Upah & 30.000 .000 & 30.000 .000 & 0.000 & 0.000 \\
\hline & $\begin{array}{l}\text { Biaya- } \\
\text { biaya lain }\end{array}$ & 10.800 .000 & $10.680 .302,68$ & 0.000 & $\overline{119.697,32}$ \\
\hline
\end{tabular}

Sumber: Hasil Olah Data (2019)

Pada tabel 10 di atas dapat dilihat bahwa berdasarkan pengukuran efisiensi model CRS yang berorientasi pada output usaha Jailani memperoleh nilai skala efisiensi sebesar 0,855 yang berarti mengalami inefisiensi. Maka untuk meningkatkan nilai skala efisien menjadi satu (1) harus ditingkatkan sebesar $1-0,855=0,145$. Usaha pembuatan tas bordir Aceh milik Jailani mengalami inefisiensi pada output kedua output yaitu pendapatan dan jumlah produksi. Adapun upaya yang dapat dilakukan oleh Jailani adalah sebagai berikut.

Pada output pendapatan terlihat bahwa dengan input yang telah digunakan Jailani memperoleh hasil sebesar Rp 120.250.000, sementara itu di target value (nilai target) yang harus dihasilkan oleh usaha Jailani untuk output pendapatan adalah sebesar Rp 135.914.239,85. Oleh karenanya untuk meningkatkan nilai skala efisiensi usahanya, Jailani harus meningkatkan pendapatannya sebesar Rp120.250.000 Rp135.914.239,85= Rp 15.664.239,85.Hal ini juga dapat dilihat pada besaran radial movement.
Sedangkan pada output jumlah produksi, usaha Jailani telah menghasilkan sejumlah 481unit, padahal usaha pembuatan tas bordir Aceh Jailani masih dapat memaksimalkan jumlah produksi sebesar nilai target yaitu 544unit. Maka untuk meningkatkan nilai skala efisiensi usaha pembuatan tas bordir Aceh Jailani harus meningkatkan jumlah produksinya sebesar radial movement yaitu 63 unit dari jumlah produksi yang telah dihasilkan guna mengefisienkan atau meningkatan nilai skala efisiensi usaha pembuatan tas bordir Aceh dengan slack movement sebesar Rp 0.

Pada, usaha pembuatan tas bordir Aceh milik Jailani bernilai target sebesar Rp 10.800.000maka untuk lebih mengefisienkan usaha pembuatan tas bordir Aceh nya Jarnaji dapat mengurangi pengeluaran pada biaya-biaya lainnya sebesar Rp10.800.000 - Rp 10.680.302,68= Rp 119.697,32. Hal ini juga dapat dilihat pada besaran nilai slack movement.

\section{Nuria}

Tabel 11

Nilai Original, Target, Radial Movement dan Slack Movement Input Output Usaha Tas Bordir Aceh Nuria Yang Inefisiensi

\begin{tabular}{|c|c|c|c|c|c|}
\hline Variabel & $\begin{array}{l}\text { Nilai } \\
\text { Efisiensi }\end{array}$ & \multirow{2}{*}{$\begin{array}{l}\text { Original } \\
\text { Value }\end{array}$} & \multirow{2}{*}{ Target Value } & \multirow{2}{*}{$\begin{array}{l}\text { Radial } \\
\text { Movement }\end{array}$} & \multirow{2}{*}{$\begin{array}{l}\text { Slack } \\
\text { Movement }\end{array}$} \\
\hline $\begin{array}{l}2018- \\
2019\end{array}$ & 0,855 & & & & \\
\hline \multirow[t]{2}{*}{ Dutput } & Pendapatan & 112.500 .000 & $158.589 .807,56$ & $46.089 .807,56$ & 0.000 \\
\hline & $\begin{array}{l}\text { Jumlah } \\
\text { Produksi }\end{array}$ & 450 & 634,359 & 184,359 & 0.000 \\
\hline \multirow[t]{3}{*}{ nput } & $\begin{array}{l}\text { Bahan } \\
\text { Baku }\end{array}$ & 24.930 .000 & 24930000 & 0.000 & 0.000 \\
\hline & Upah & 60.000 .000 & $42.008 .553,1$ & 0.000 & $\begin{array}{l}- \\
17.991 .446,900\end{array}$ \\
\hline & $\begin{array}{l}\text { Biaya- } \\
\text { biaya lain }\end{array}$ & 12.000 .000 & 12.000 .000 & 0.000 & 0.000 \\
\hline
\end{tabular}

Sumber: Hasil Olah Data (2019)

Pada tabel 11 di atas dapat dilihat bahwa berdasarkan pengukuran efisiensi model CRS yang berorientasi pada output usaha Nuria memperoleh nilai skala efisiensi sebesar 0,855 yang berarti mengalami inefisiensi. Maka untuk meningkatkan nilai skala efisien menjadi satu (1) harus ditingkatkan sebesar $1-0,855=0,145$. Usaha pembuatan tas bordir Aceh milik Nuria mengalami inefisiensi pada kedua output yaitu pendapatan dan jumlah produksi. Adapun upaya yang dapat dilakukan oleh Nuria adalah sebagai berikut.

Pada output pendapatan terlihat bahwa dengan input yang telah digunakan Nuria memperoleh hasil sebesar Rp 112.500.000, sementara itu di target value (nilai target) yang 
harus dihasilkan oleh usaha Nuria untuk output pendapatan adalah sebesar Rp 158.589.807,56. Oleh karenanya untuk meningkatkan nilai skala efisiensi usahanya, Nuria harus meningkatkan pendapatannya sebesar Rp112.500.000 - Rp 158.589.807,56= Rp 46.089.807,56.Hal ini juga dapat dilihat pada besaran radial movement.

Sedangkan pada output jumlah produksi, usaha Nuria telah menghasilkan sejumlah 450unit, padahal usaha pembuatan tas bordir Aceh Nuria masih dapat memaksimalkan jumlah produksi sebesar nilai target yaitu 634unit. Maka untuk meningkatkan nilai skala efisiensi usaha pembuatan tas bordir Aceh Nuria harus meningkatkan jumlah produksinya sebesar radial movement yaitu 184 unit dari jumlah produksi yang telah dihasilkan guna mengefisienkan atau meningkatan nilai skala efisiensi usaha pembuatan tas bordir Aceh dengan slack movement sebesar Rp 0.

Pada, usaha pembuatan tas bordir Aceh milik Nuria bernilai target sebesar Rp 42.008.553,1 maka untuk lebih mengefisienkan usaha pembuatan tas bordir Aceh nya Jarnaji dapat mengurangi pengeluaran pada upah sebesar Rp $60.000 .000 \quad-\mathrm{Rp} 42.008 .553,1 \quad=\mathrm{Rp}$ 17.991.446,900. Hal ini juga dapat dilihat pada besaran nilai slack movement.

\section{Putrona}

Tabel 12

Nilai Original, Target, Radial Movement dan Slack Movement Input Output Usaha Tas Bordir Aceh Putrona Yang Inefisiensi

\begin{tabular}{|c|c|c|c|c|c|}
\hline Variabel & $\begin{array}{l}\text { Nilai } \\
\text { Efisiensi }\end{array}$ & \multirow{2}{*}{$\begin{array}{l}\text { Original } \\
\text { Value }\end{array}$} & \multirow[t]{2}{*}{ Target Value } & \multirow{2}{*}{$\begin{array}{l}\text { Radial } \\
\text { Movement }\end{array}$} & \multirow{2}{*}{$\begin{array}{l}\text { Slack } \\
\text { Movement }\end{array}$} \\
\hline 2018-2019 & 0,925 & & & & \\
\hline \multirow[t]{2}{*}{ Dutput } & Pendapatan & 116.750 .000 & $126.257 .711,26$ & $9.507 .711,26$ & 0.000 \\
\hline & $\begin{array}{l}\text { Jumlah } \\
\text { Produksi }\end{array}$ & 467 & 505,031 & 38,031 & 0.000 \\
\hline \multirow[t]{3}{*}{ nput } & $\begin{array}{l}\text { Bahan } \\
\text { Baku }\end{array}$ & 20.290 .000 & 20.290 .000 & 0.000 & 0.000 \\
\hline & Upah & 30.000 .000 & 30.000 .000 & 0.000 & 0.000 \\
\hline & $\begin{array}{l}\text { Biaya- } \\
\text { biaya lain }\end{array}$ & 9.600 .000 & 9.600 .000 & 0.000 & 0.000 \\
\hline
\end{tabular}

Sumber: Hasil Olah Data (2019)

Pada tabel 12 di atas dapat dilihat bahwa berdasarkan pengukuran efisiensi model CRS yang berorientasi pada output usaha Putrona memperoleh nilai skala efisiensi sebesar 0,925 yang berarti mengalami inefisiensi. Maka untuk meningkatkan nilai skala efisien menjadi satu (1) harus ditingkatkan sebesar 1-0,925=0,075. Usaha pembuatan tas bordir Aceh milik Putrona mengalami inefisiensi pada output kedua output yaitu pendapatan dan jumlah produksi. Adapun upaya yang dapat dilakukan oleh Putrona adalah sebagai berikut.

Pada output pendapatan terlihat bahwa dengan input yang telah digunakan Putrona memperoleh hasil sebesar Rp 116.750.000, sementara itu di target value (nilai target) yang harus dihasilkan oleh usaha Putrona untuk output pendapatan adalah sebesar Rp 126.257.711,26. Oleh karenanya untuk meningkatkan nilai skala efisiensi usahanya, Putrona harus meningkatkan pendapatannya sebesar Rp 126.257.711,26Rp116.750.000 = Rp 9.507.711,26.Hal ini juga dapat dilihat pada besaran radial movement.

Sedangkan pada output jumlah produksi, usaha Putrona telah menghasilkan sejumlah 467 unit, padahal usaha pembuatan tas bordir Aceh Putrona masih dapat memaksimalkan jumlah produksi sebesar nilai target yaitu 505unit. Maka untuk meningkatkan nilai skala efisiensi usaha pembuatan tas bordir Aceh Putrona harus meningkatkan jumlah produksinya sebesar radial movement yaitu 38 unit dari jumlah produksi yang telah dihasilkan guna mengefisienkan atau meningkatan nilai skala efisiensi usaha pembuatan tas bordir Aceh dengan slack movement sebesar Rp 0.

\section{Pelita}

\section{Tabel 13}

Nilai Original, Target, Radial Movement dan Slack Movement Input Output Usaha Tas Bordir Aceh Pelita Yang Inefisiensi

\begin{tabular}{|c|c|c|c|c|c|}
\hline Variabel & $\begin{array}{l}\text { Nilai } \\
\text { Efisiensi }\end{array}$ & \multirow{2}{*}{$\begin{array}{l}\text { Original } \\
\text { Value }\end{array}$} & \multirow[b]{2}{*}{ Target Value } & \multirow{2}{*}{$\begin{array}{l}\text { Radial } \\
\text { Movement }\end{array}$} & \multirow{2}{*}{$\begin{array}{l}\text { Slack } \\
\text { Movement }\end{array}$} \\
\hline $\begin{array}{l}2018- \\
2019\end{array}$ & 0,836 & & & & \\
\hline \multirow[t]{2}{*}{ Putput } & Pendapatan & 122.000 .000 & $145.887 .562,37$ & $23.887 .562,37$ & 0.000 \\
\hline & $\begin{array}{l}\text { Jumlah } \\
\text { Produksi }\end{array}$ & 488 & 583,550 & 95,550 & 0.000 \\
\hline \multirow[t]{3}{*}{ nput } & $\begin{array}{l}\text { Bahan } \\
\text { Baku }\end{array}$ & 23.140 .000 & 23.140 .000 & 0.000 & 0.000 \\
\hline & Upah & 48.000 .000 & $38.108 .339,27$ & 0.000 & $\overline{9.891 .660,73}$ \\
\hline & $\begin{array}{l}\text { Biaya- } \\
\text { biaya lain }\end{array}$ & 10.800 .000 & 10.800 .000 & 0.000 & 0.000 \\
\hline
\end{tabular}

Sumber: Hasil Olah Data (2019)

Pada tabel 13 di atas dapat dilihat bahwa berdasarkan pengukuran efisiensi model CRS yang berorientasi pada output usaha Pelita memperoleh nilai skala efisiensi sebesar 0,836 yang berarti mengalami inefisiensi. Maka untuk meningkatkan nilai skala efisien menjadi satu (1) harus ditingkatkan sebesar 1-0,836 =0,164. Usaha pembuatan tas bordir Aceh milik Pelita mengalami inefisiensi pada output kedua output yaitu pendapatan dan jumlah produksi. Adapun upaya 
yang dapat dilakukan oleh Pelita adalah sebagai berikut.

Pada output pendapatan terlihat bahwa dengan input yang telah digunakan Pelita memperoleh hasil sebesar $\mathrm{Rp}$ 122.000.000, sementara itu di target value (nilai target) yang harus dihasilkan oleh usaha Pelita untuk output pendapatan adalah sebesar Rp 145.887.562,37. Oleh karenanya untuk meningkatkan nilai skala efisiensi usahanya, Pelita harus meningkatkan pendapatannya sebesar Rp 145.887.562,37- Rp $122.000 .000=\operatorname{Rp} 23.887 .562,37$. Hal ini juga dapat dilihat pada besaran radial movement.

Sedangkan pada output jumlah produksi, usaha Pelita telah menghasilkan sejumlah 488unit, padahal usaha pembuatan tas bordir Aceh Pelita masih dapat memaksimalkan jumlah produksi sebesar nilai target yaitu 584 unit. Maka untuk meningkatkan nilai skala efisiensi usaha pembuatan tas bordir Aceh Pelita harus meningkatkan jumlah produksinya sebesar radial movement yaitu 96unit dari jumlah produksi yang telah dihasilkan guna mengefisienkan atau meningkatan nilai skala efisiensi usaha pembuatan tas bordir Aceh dengan slack movement sebesar Rp 0.

Pada input upah, usaha pembuatan tas bordir Aceh milik Pelita bernilai target sebesar Rp 38.108.339,27 maka untuk lebih mengefisienkan usaha pembuatan tas bordir Aceh nya Pelita dapat mengurangi pengeluaran pada upah sebesar slack movement yaitu $\mathrm{Rp} 9.891 .660,73$.

\section{Pelita Sri Maryati}

\section{Tabel 14}

Nilai Original, Target, Radial Movement dan

Slack Movement Input Output Usaha Tas Bordir AcehPelita Sri Maryati Yang Inefisiensi

\begin{tabular}{|l|l|l|l|l|l|}
\hline Variabel & $\begin{array}{l}\text { Nilai } \\
\text { Efisiensi }\end{array}$ & $\begin{array}{l}\text { Original } \\
\text { Value }\end{array}$ & Target Value & $\begin{array}{l}\text { Radial } \\
\text { Movement }\end{array}$ & $\begin{array}{l}\text { Slack } \\
\text { Movement }\end{array}$ \\
\hline $\begin{array}{l}\mathbf{2 0 1 8 -} \\
\mathbf{2 0 1 9}\end{array}$ & $\mathbf{0 , 8 6 9}$ & & & & \\
\hline putput & Pendapatan & 114.750 .000 & $132.024 .776,42$ & $17.274 .776,42$ & 0.000 \\
\cline { 2 - 6 } & $\begin{array}{l}\text { Jumlah } \\
\text { Produksi }\end{array}$ & 459 & 528,099 & 69,099 & 0.000 \\
\hline nput & $\begin{array}{l}\text { Bahan } \\
\text { Baku }\end{array}$ & 20.160 .000 & 20.160 .000 & 0.000 & 0.000 \\
\cline { 2 - 5 } & Upah & 36.000 .000 & 36.000 .000 & 0.000 & 0.000 \\
\cline { 2 - 5 } & $\begin{array}{l}\text { Biaya- } \\
\text { biaya lain }\end{array}$ & 10.800 .000 & 10.800 .000 & 0.000 & 0.000 \\
\hline
\end{tabular}

Sumber: Hasil Olah Data (2019)

Pada tabel 14 di atas dapat dilihat bahwa berdasarkan pengukuran efisiensi model CRS yang berorientasi pada output usaha Pelita Sri Maryati memperoleh nilai skala efisiensi sebesar 0,869 yang berarti mengalami inefisiensi. Maka untuk meningkatkan nilai skala efisien menjadi satu (1) harus ditingkatkan sebesar $1-0,869=0,131$. Usaha pembuatan tas bordir Aceh milik Pelita Sri Maryati mengalami inefisiensi pada kedua output yaitu pendapatan dan jumlah produksi. Adapun upaya yang dapat dilakukan oleh Pelita Sri Maryati adalah sebagai berikut.

Pada output pendapatan terlihat bahwa dengan input yang telah digunakan Pelita Sri Maryati memperoleh hasil sebesar Rp 114.750.000, sementara itu di target value (nilai target) yang harus dihasilkan oleh usaha Pelita Sri Maryati untuk output pendapatan adalah sebesar Rp 132.024.776,42. Oleh karenanya untuk meningkatkan nilai skala efisiensi usahanya, Pelita Sri Maryati harus meningkatkan pendapatannya sebesar Rp 132.024.776,42- Rp 114.750.000 = Rp 17.274.776,42.Hal ini juga dapat dilihat pada besaran radial movement.

Sedangkan pada output jumlah produksi, usaha PelitaSri Maryati telah menghasilkan sejumlah 459unit, padahal usaha pembuatan tas bordir Aceh PelitaSri Maryati masih dapat memaksimalkan jumlah produksi sebesar nilai target yaitu 528 unit. Maka untuk meningkatkan nilai skala efisiensi usaha pembuatan tas bordir Aceh Pelita Sri Maryati harus meningkatkan jumlah produksinya sebesar radial movement yaitu 69unit dari jumlah produksi yang telah dihasilkan guna mengefisienkan atau meningkatan nilai skala efisiensi usaha pembuatan tas bordir Aceh dengan slack movement sebesar Rp 0.

\section{Sanyo Bag}

\section{Tabel 15}

Nilai Original, Target, Radial Movement dan Slack Movement Input Output Usaha Tas Bordir Aceh Sanyo Bag Yang Inefisiensi

\begin{tabular}{|c|c|c|c|c|c|}
\hline Variabel & $\begin{array}{l}\text { Nilai } \\
\text { Efisiensi }\end{array}$ & \multirow{2}{*}{ Original Value } & \multirow{2}{*}{ Target Value } & \multirow{2}{*}{$\begin{array}{l}\text { Radial } \\
\text { Movement }\end{array}$} & \multirow{2}{*}{$\begin{array}{l}\text { Slack } \\
\text { Movement }\end{array}$} \\
\hline 2018-2019 & 0,934 & & & & \\
\hline \multirow{2}{*}{ utput } & Pendapatan & 122.750 .000 & $131.430 .689,91$ & $8.680 .689,91$ & 0.000 \\
\hline & $\begin{array}{l}\text { Jumlah } \\
\text { Produksi }\end{array}$ & 491 & 525,723 & 34,723 & 0.000 \\
\hline \multirow[t]{3}{*}{ nput } & $\begin{array}{l}\text { Bahan } \\
\text { Baku }\end{array}$ & 20.020 .000 & 20.020 .000 & 0.000 & 0.000 \\
\hline & Upah & 36.000 .000 & 36.000 .000 & 0.000 & 0.000 \\
\hline & $\begin{array}{l}\text { Biaya- } \\
\text { biaya lain }\end{array}$ & 10.800 .000 & $\begin{array}{l}10.800 .000 \\
\end{array}$ & 0.000 & 0.000 \\
\hline
\end{tabular}

Sumber: Hasil Olah Data (2019)

Pada tabel 15 di atas dapat dilihat bahwa berdasarkan pengukuran efisiensi model CRS yang berorientasi pada output usaha Sanyo Bag memperoleh nilai skala efisiensi sebesar 0,934 yang berarti mengalami inefisiensi. Maka untuk meningkatkan nilai skala efisien menjadi satu (1) 
harus ditingkatkan sebesar 1-0,934=0,066. Usaha pembuatan tas bordir Aceh milik Sanyo Bag mengalami inefisiensi pada kedua output yaitu pendapatan dan jumlah produksi. Adapun upaya yang dapat dilakukan oleh Sanyo Bag adalah sebagai berikut.

Pada output pendapatan terlihat bahwa dengan input yang telah digunakan Sanyo Bag memperoleh hasil sebesar Rp 122.750.000, sementara itu di target value (nilai target) yang harus dihasilkan oleh usaha Sanyo Bag untuk output pendapatan adalah sebesar $\mathrm{Rp}$ 131.430.689,91. Oleh karenanya untuk meningkatkan nilai skala efisiensi usahanya, Sanyo Bag harus meningkatkan pendapatannya sebesar Rp 131.430.689,9- Rp 122.750.000= Rp 8.680.689,91.Hal ini juga dapat dilihat pada besaran nilai radial movement.

Sedangkan pada output jumlah produksi, usaha Sanyo Bag telah menghasilkan sejumlah 491unit, padahal usaha pembuatan tas bordir Aceh Sanyo Bag masih dapat memaksimalkan jumlah produksi sebesar nilai target yaitu 526 unit. Maka untuk meningkatkan nilai skala efisiensi usaha pembuatan tas bordir Aceh Sanyo Bag harus meningkatkan jumlah produksinya sebesar radial movement yaitu 35unit dari jumlah produksi yang telah dihasilkan guna mengefisienkan atau meningkatan nilai skala efisiensi usaha pembuatan tas bordir Aceh dengan slack movement sebesar Rp 0.

\section{Naiart Cop Tah}

\section{Tabel 16}

Nilai Original, Target, Radial Movement dan Slack Movement Input Output Usaha Tas Bordir Aceh Naiart Cop Tah Yang Inefisiensi

\begin{tabular}{|c|c|c|c|c|c|}
\hline Variabel & $\begin{array}{l}\text { Nilai } \\
\text { Efisiensi } \\
\end{array}$ & \multirow[t]{2}{*}{$\begin{array}{l}\text { Original } \\
\text { Value }\end{array}$} & \multirow[t]{2}{*}{ Target Value } & \multirow[t]{2}{*}{$\begin{array}{l}\text { Radial } \\
\text { Movement }\end{array}$} & \multirow[t]{2}{*}{$\begin{array}{l}\text { Slack } \\
\text { Movement }\end{array}$} \\
\hline 2018-2019 & 0,945 & & & & \\
\hline \multirow[t]{2}{*}{ Putput } & Pendapatan & 123.750 .000 & $130.954 .545,45$ & $720.454,45$ & 0.000 \\
\hline & $\begin{array}{l}\text { Jumlah } \\
\text { Produksi }\end{array}$ & 495 & 523,818 & 28,818 & 0.000 \\
\hline \multirow[t]{3}{*}{ nput } & $\begin{array}{l}\text { Bahan } \\
\text { Baku }\end{array}$ & 24.680 .000 & $21.836 .969,697$ & 0.000 & $\begin{array}{l}- \\
2.843 .030,303\end{array}$ \\
\hline & Upah & 30.000 .000 & 30.000 .000 & 0.000 & 0.000 \\
\hline & $\begin{array}{l}\text { Biaya- } \\
\text { biaya lain }\end{array}$ & 9.600 .000 & 9.600 .000 & 0.000 & 0.000 \\
\hline
\end{tabular}

Sumber: Hasil Olah Data (2019)

Pada tabel 16 di atas dapat dilihat bahwa berdasarkan pengukuran efisiensi model CRS yang berorientasi pada output usaha Naiart Cop Tahmemperoleh nilai skala efisiensi sebesar 0,945 yang berarti mengalami inefisiensi. Maka untuk meningkatkan nilai skala efisien menjadi satu (1) harus ditingkatkan sebesar $1-0,945=0,055$. Usaha pembuatan tas bordir Aceh milik Naiart Cop Tahmengalami inefisiensi pada kedua output yaitu pendapatan dan jumlah produksi. Adapun upaya yang dapat dilakukan oleh Naiart Cop Tahadalah sebagai berikut.

Pada output pendapatan terlihat bahwa dengan input yang telah digunakan Naiart Cop Tahmemperoleh hasil sebesar Rp 123.750.000, sementara itu di target value (nilai target) yang harus dihasilkan oleh usaha Naiart Cop Tahuntuk output pendapatan adalah sebesar Rp130.954.545,45. Oleh karenanya untuk meningkatkan nilai skala efisiensi usahanya, Naiart Cop Tah harus meningkatkan pendapatannya sebesar Rp 130.954.545,45- Rp $123.750 .000=\operatorname{Rp} 720.454,45$. Hal ini juga dapat dilihat pada besaran nilai radial movement.

Sedangkan pada output jumlah produksi, usaha Naiart Cop Tah telah menghasilkan sejumlah 495unit, padahal usaha pembuatan tas bordir Aceh Naiart Cop Tah masih dapat memaksimalkan jumlah produksi sebesar nilai target yaitu 524 unit. Maka untuk meningkatkan nilai skala efisiensi usaha pembuatan tas bordir Aceh Naiart Cop Tah harus meningkatkan jumlah produksinya sebesar radial movement yaitu 29unit dari jumlah produksi yang telah dihasilkan guna mengefisienkan atau meningkatan nilai skala efisiensi usaha pembuatan tas bordir Aceh dengan slack movement sebesar Rp 0.

Pada input bahan baku, usaha pembuatan tas bordir Aceh milik Naiart Cop Tah bernilai target sebesar $\mathrm{Rp}$ 21.836.969,697 maka untuk lebih mengefisienkan usaha pembuatan tas bordir Aceh nya Naiart Cop Tah dapat mengurangi pengeluaran pada bahan baku sebesar slack movement yaitu $\mathrm{Rp} 2.843 .030,303$.

\section{Nisa}

Tabel 17

Nilai Original, Target, Radial Movement dan Slack Movement Input Output Usaha Tas Bordir Aceh Nisa yang Inefisiensi

\begin{tabular}{|c|l|l|l|l|l|}
\hline Variabel & $\begin{array}{l}\text { Nilai } \\
\text { Efisiensi }\end{array}$ & $\begin{array}{l}\text { Original } \\
\text { Value }\end{array}$ & Target Value & $\begin{array}{l}\text { Radial } \\
\text { Movement }\end{array}$ & $\begin{array}{l}\text { Slack } \\
\text { Movement }\end{array}$ \\
\hline 2018-2019 & $\mathbf{0 , 8 3 8}$ & 123.750 .000 & $147.593 .905,92$ & $23.843 .905,92$ & 0.000 \\
\hline Dutput & Pendapatan & nnty &
\end{tabular}




\begin{tabular}{|l|l|l|l|l|l|}
\cline { 3 - 6 } & $\begin{array}{l}\text { Jumlah } \\
\text { Produksi }\end{array}$ & 495 & 590,376 & 95,376 & 0.000 \\
\hline nput & $\begin{array}{l}\text { Bahan } \\
\text { Baku }\end{array}$ & 23.520 .000 & 23.520 .000 & 0.000 & 0.000 \\
\cline { 2 - 6 } & Upah & 42.000 .000 & $38.270 .848,18$ & 0.000 & $-3.729 .151,82$ \\
\cline { 2 - 6 } & $\begin{array}{l}\text { Biaya- } \\
\text { biaya lain }\end{array}$ & 10.800 .000 & 10.800 .000 & 0.000 & 0.000 \\
\hline
\end{tabular}

Sumber: Hasil Olah Data (2019)

Pada tabel 17 di atas dapat dilihat bahwa berdasarkan pengukuran efisiensi model CRS yang berorientasi pada output usaha Nisa memperoleh nilai skala efisiensi sebesar 0,838 yang berarti mengalami inefisiensi. Maka untuk meningkatkan nilai skala efisien menjadi satu $(=1)$ harus ditingkatkan sebesar $1-0,838=0,162$. Usaha pembuatan tas bordir Aceh milik Nisa mengalami inefisiensi pada kedua output yaitu pendapatan dan jumlah produksi. Adapun upaya yang dapat dilakukan oleh Nisa adalah sebagai berikut.

Pada output pendapatan terlihat bahwa dengan input yang telah digunakan Nisa memperoleh hasil sebesar Rp 123.750.000, sementara itu di target value (nilai target) yang harus dihasilkan oleh usaha Nisa untuk output pendapatan adalah sebesar Rp 147.593.905,92. Oleh karenanya untuk meningkatkan nilai skala efisiensi usahanya, Nisa harus meningkatkan pendapatannya sebesar Rp 147.593.905,92- Rp $123.750 .000=\operatorname{Rp} 23.843 .905,92$. Hal ini juga dapat dilihat pada besaran nilai radial movement.

Sedangkan pada output jumlah produksi, usaha Nisa telah menghasilkan sejumlah 495unit, padahal usaha pembuatan tas bordir Aceh Nisa masih dapat memaksimalkan jumlah produksi sebesar nilai target yaitu 590 unit. Maka untuk meningkatkan nilai skala efisiensi usaha pembuatan tas bordir Aceh Nisa harus meningkatkan jumlah produksinya sebesar radial movement yaitu 95unit dari jumlah produksi yang telah dihasilkan guna mengefisienkan atau meningkatan nilai skala efisiensi usaha pembuatan tas bordir Aceh dengan slack movement sebesar Rp 0.

Pada input input upah, usaha pembuatan tas bordir Aceh milik Nisa bernilai target sebesar Rp 38.270.848,18 maka untuk lebih mengefisienkan usaha pembuatan tas bordir Aceh nya Nisa dapat mengurangi pengeluaran pada input upah sebesar slack movement yaitu $\mathrm{Rp}$ 3.729.151,82.

\section{Zaini}

\section{Tabel 18 \\ Nilai Original, Target, Radial Movement dan Slack Movement Input Output Usaha Tas Bordir AcehZaini yang Inefisiensi}

\begin{tabular}{|c|c|c|c|c|c|}
\hline Variabel & $\begin{array}{l}\text { Nilai } \\
\text { Efisiensi }\end{array}$ & \multirow{2}{*}{$\begin{array}{l}\text { Original } \\
\text { Value }\end{array}$} & \multirow{2}{*}{ Target Value } & \multirow{2}{*}{$\begin{array}{l}\text { Radial } \\
\text { Movement }\end{array}$} & \multirow{2}{*}{$\begin{array}{l}\text { Slack } \\
\text { Movement }\end{array}$} \\
\hline $\begin{array}{l}2018- \\
2019\end{array}$ & 0,909 & & & & \\
\hline \multirow[t]{2}{*}{ putput } & Pendapatan & 119.500 .000 & $131.518 .353,53$ & $12.018 .353,53$ & 0.000 \\
\hline & $\begin{array}{l}\text { Jumlah } \\
\text { Produksi }\end{array}$ & 478 & 526,073 & 48,073 & 0.000 \\
\hline \multirow[t]{3}{*}{ nput } & $\begin{array}{l}\text { Bahan } \\
\text { Baku }\end{array}$ & 19.940 .000 & 19.940 .000 & 0.000 & 0.000 \\
\hline & Upah & 48.000 .000 & $36.739 .843,193$ & 0.000 & $-\overline{11.260 .156,807}$ \\
\hline & $\begin{array}{l}\text { Biaya- } \\
\text { biaya lain }\end{array}$ & 10.800 .000 & 10.800 .000 & 0.000 & 0.000 \\
\hline
\end{tabular}

Sumber: Hasil Olah Data (2019)

Pada tabel 18 di atas dapat dilihat bahwa berdasarkan pengukuran efisiensi model CRS yang berorientasi pada output usaha Zainimemperoleh nilai skala efisiensi sebesar 0,909 yang berarti mengalami inefisiensi. Maka untuk meningkatkan nilai skala efisien menjadi satu (1) harus ditingkatkan sebesar 1-0,909 = 0,091 . Usaha pembuatan tas bordir Aceh milik Zainimengalami inefisiensi pada kedua output yaitu pendapatan dan jumlah produksi. Adapun upaya yang dapat dilakukan oleh Zainiadalah sebagai berikut.

Pada output pendapatan terlihat bahwa dengan input yang telah digunakan Zainimemperoleh hasil sebesar Rp 119.500.000, sementara itu di target value (nilai target) yang harus dihasilkan oleh usaha Zainiuntuk output pendapatan adalah sebesar Rp 131.518.353,53. Oleh karenanya untuk meningkatkan nilai skala efisiensi usahanya, Zaini harus meningkatkan pendapatannya sebesar Rp 131.518.353,53- Rp $119.500 .000=\operatorname{Rp} 12.018 .353,53$. Hal ini juga dapat dilihat pada besaran nilai radial movement.

Sedangkan pada output jumlah produksi, usaha Zaini telah menghasilkan sejumlah 478unit, padahal usaha pembuatan tas bordir Aceh Zaini masih dapat memaksimalkan jumlah produksi sebesar nilai target yaitu 526 unit. Maka untuk meningkatkan nilai skala efisiensi usaha pembuatan tas bordir Aceh Zaini harus meningkatkan jumlah produksinya sebesar radial movement yaitu 48unit dari jumlah produksi yang telah dihasilkan guna mengefisienkan atau meningkatan nilai skala efisiensi usaha pembuatan tas bordir Aceh dengan slack movement sebesar Rp 0. 
Pada input input upah, usaha pembuatan tas bordir Aceh milik Zaini bernilai target sebesar Rp 36.739.843,193 maka untuk lebih mengefisienkan usaha pembuatan tas bordir Aceh nya Zaini dapat mengurangi pengeluaran pada input upah sebesar slack movement yaitu $\mathrm{Rp}$ 11.260.156,807.

\section{Tingkat Efisiensi Usaha Pembuatan Tas Bordir} Aceh dengan Menggunakan VRS Output Oriented DEA

\section{Jarjani}

\section{Tabel 19}

Nilai Original, Target, Radial Movement dan Slack Movement Input Output Usaha Tas Bordir Aceh Jarjani Yang Inefisiensi

\begin{tabular}{|l|l|l|l|l|l|}
\hline Variabel & $\begin{array}{l}\text { Nilai } \\
\text { Efisiensi }\end{array}$ & $\begin{array}{l}\text { Original } \\
\text { Value }\end{array}$ & Target Value & $\begin{array}{l}\text { Radial } \\
\text { Movement }\end{array}$ & $\begin{array}{l}\text { Slack } \\
\text { Movement }\end{array}$ \\
\hline 2018-2019 & $\mathbf{0 , 9 2 5}$ & 118.000 .000 & 127.500 .000 & 9.500 .000 & 0.000 \\
\hline \multirow{3}{*}{ putput } & Pendapatan & 172 & 510 & 38 & 0.000 \\
\cline { 2 - 5 } & $\begin{array}{l}\text { Jumlah } \\
\text { Produksi }\end{array}$ & 472 & 23.080 .000 & 0.000 & -140.000 \\
& $\begin{array}{l}\text { Bahan } \\
\text { Baku }\end{array}$ & 23.220 .000 & & & -16.000 .000 \\
\cline { 2 - 5 } & Upah & 54.000 .000 & 38.000 .000 & 0.000 & -1.200 .000 \\
\cline { 2 - 5 } & $\begin{array}{l}\text { Biaya- } \\
\text { biaya lain }\end{array}$ & 12.000 .000 & 10.800 .000 & 0.000 & \\
\hline
\end{tabular}

Sumber: Hasil Olah Data (2019)

Pada tabel 19 di atas dapat dilihat bahwa berdasarkan pengukuran efisiensi model VRS yang berorientasi pada output usaha Jarjani memperoleh nilai skala efisiensi sebesar 0,925 yang berarti bahwa mengalami inefisiensi. Maka untuk meningkatkan nilai skala efisien menjadi satu (1) harus ditingkatkan sebesar $1-0,925=$ 0,075. Usaha pembuatan tas bordir Aceh milik Jarjani mengalami inefisiensi pada kedua output yaitu pendapatan dan jumlah produksi namun usaha Jarjani masih dapat lebih mengefisienkan usaha pembuatan tas bordir Aceh dengan mengurangi pengeluaran pada ketiga input yaitu bahan baku, upah, dan biaya-biaya lain sebesar slack movement. Adapun upaya yang dapat dilakukan oleh Jarjani adalah sebagai berikut.

Pada output pendapatan terlihat bahwa dengan input yang telah digunakan Jarjani memperoleh hasil sebesar $\mathrm{Rp}$ 118.000.000, sementara itu di target value (nilai target) yang harus dihasilkan oleh usaha Jarjani untuk output pendapatan adalah sebesar Rp 127.500.000. Oleh karenanya untuk meningkatkan nilai skala efisiensi usahanya, Jarjani harus meningkatkan pendapatannya sebesar Rp 127.500.000 - Rp
118.000.000= Rp 9.500.000 hal ini juga dapat dilihat pada besaran nilai radial movement.

Sedangkan pada output jumlah produksi, usaha Jarjani telah menghasilkan sejumlah 472 unit, padahal usaha pembuatan tas bordir Aceh Jarjani masih dapat memaksimalkan jumlah produksi sebesar nilai target yaitu 510 unit. Maka untuk meningkatkan nilai skala efisiensi usaha pembuatan tas bordir Aceh Jarjani harus meningkatkan jumlah produksinya sebesar radial movement yaitu 38 unit dari jumlah produksi yang telah dihasilkan guna mengefisienkan atau meningkatan nilai skala efisiensi usaha pembuatan tas bordir Aceh Jarjani dengan slack movement sebesar Rp 0.

Untuk lebih mengefisienkan penggunaan input, usaha pembuatan tas bordir Aceh milik Jarjani dapat mengurangi input bahan baku sebesar Rp 140.000, input upah sebesar Rp 16.000.000, dan input biaya-biaya lainnya sebesar Rp 1.200.000. Hal ini sesuai dengan hasil pengurangan nilai target dan nilai original atau dapat juga dilihat dari besaran nilai slack movement.

\section{Tabina}

\section{Tabel 20}

Nilai Original, Target, Radial Movement dan Slack Movement Input Output Usaha Tas Bordir Aceh Tabina Yang Inefisiensi

\begin{tabular}{|c|c|c|c|c|c|}
\hline Variabel & $\begin{array}{l}\text { Nilai } \\
\text { Efisiensi } \\
\end{array}$ & \multirow{2}{*}{$\begin{array}{l}\text { Original } \\
\text { Value }\end{array}$} & \multirow{2}{*}{ Target Value } & \multirow{2}{*}{$\begin{array}{l}\text { Radial } \\
\text { Movement }\end{array}$} & \multirow{2}{*}{$\begin{array}{l}\text { Slack } \\
\text { Movement }\end{array}$} \\
\hline $\begin{array}{l}2018- \\
2019\end{array}$ & 0,972 & & & & \\
\hline \multirow[t]{2}{*}{ output } & Pendapatan & 122.250 .000 & $125.792 .200,62$ & 3.542 .200 .619 & 0.000 \\
\hline & $\begin{array}{l}\text { Jumlah } \\
\text { Produksi }\end{array}$ & 489 & 503,169 & 14,169 & 0.000 \\
\hline \multirow[t]{3}{*}{ nput } & $\begin{array}{l}\text { Bahan } \\
\text { Baku }\end{array}$ & 19.770 .000 & 19770000 & 0.000 & 0.000 \\
\hline & Upah & 36.000 .000 & & 0.000 & 0.000 \\
\hline & $\begin{array}{l}\text { Biaya- } \\
\text { biaya lain }\end{array}$ & 10.800 .000 & $10.743 .791,427$ & 0.000 & $\begin{array}{l}- \\
56.208,573\end{array}$ \\
\hline
\end{tabular}

Sumber: Hasil Olah Data (2019)

Pada tabel 20 di atas dapat dilihat bahwa berdasarkan pengukuran efisiensi model VRS yang berorientasi pada output usaha Tabina memperoleh nilai skala efisiensi sebesar 0,972 yang berarti bahwa mengalami inefisiensi. Maka untuk meningkatkan nilai skala efisien menjadi satu (1) harus ditingkatkan sebesar 1 - 0,972= 0,028 . Usaha pembuatan tas bordir Aceh milik Tabina mengalami inefisiensi pada kedua output yaitu pendapatan dan jumlah produksi namun usaha Tabina masih dapat lebih mengefisienkan usaha pembuatan tas bordir Aceh dengan mengurangi pengeluaran pada ketiga input yaitu 
bahan baku, upah, dan biaya-biaya lain sebesar slack movement. Adapun upaya yang dapat dilakukan oleh Tabina adalah sebagai berikut.

Pada output pendapatan terlihat bahwa dengan input yang telah digunakan Tabina memperoleh hasil sebesar Rp 122.250.000, sementara itu di target value (nilai target) yang harus dihasilkan oleh usaha Tabina untuk output pendapatan adalah sebesar Rp 125.792.200,62. Oleh karenanya untuk meningkatkan nilai skala efisiensi usahanya, Tabina harus meningkatkan pendapatannya sebesar Rp 125.792.200,62- Rp $122.250 .000=\operatorname{Rp} 3.542 .200 .62$. Hal ini juga dapat dilihat pada besaran nilai radial movement.

Sedangkan pada output jumlah produksi, usaha Tabina telah menghasilkan sejumlah 489 unit, padahal usaha pembuatan tas bordir Aceh Tabina masih dapat memaksimalkan jumlah produksi sebesar nilai target yaitu 503 unit. Maka untuk meningkatkan nilai skala efisiensi usaha pembuatan tas bordir Aceh Tabina harus meningkatkan jumlah produksinya sebesar radial movement yaitu 49 unit dari jumlah produksi yang telah dihasilkan guna mengefisienkan atau meningkatan nilai skala efisiensi usaha pembuatan tas bordir Aceh Tabina dengan slack movement sebesar Rp 0.

Untuk lebih mengefisienkan penggunaan input, usaha pembuatan tas bordir Aceh milik Tabina dapat mengurangi input biaya-biaya lainnya sebesar $\mathrm{Rp}$ 56.208,573. Hal ini sesuai dengan hasil pengurangan nilai target dan nilai original atau dapat juga dilihat dari besaran nilai slack movement.

Untuk lebih mengefisienkan penggunaan input, usaha pembuatan tas bordir Aceh milik Tabina dapat mengurangi input biaya-biaya lainnya sebesar Rp 56.208,573. Hal ini sesuai dengan nilai target dan besaran slack movement.

\section{Marzuki}

Tabel 21

Nilai Original, Target, Radial Movement dan Slack Movement Input Output Usaha Tas Bordir Aceh Marzuki Yang Inefisiensi Dengan Tingkat Efisiensi

\begin{tabular}{|l|l|l|l|l|l|}
\hline Variabel & $\begin{array}{l}\text { Nilai } \\
\text { Efisiensi }\end{array}$ & $\begin{array}{l}\text { Original } \\
\text { Value }\end{array}$ & Target Value & $\begin{array}{l}\text { Radial } \\
\text { Movement }\end{array}$ & $\begin{array}{l}\text { Slack } \\
\text { Movement }\end{array}$ \\
\hline
\end{tabular}

\begin{tabular}{|l|l|l|l|l|l|}
\cline { 2 - 6 } 2018-2019 & $\mathbf{0 , 9 1 7}$ & & & & \\
\hline \multirow{3}{*}{ utput } & Pendapatan & 116.500 .000 & 127.000 .000 & 10.500 .000 & 0.000 \\
\cline { 2 - 6 } & $\begin{array}{l}\text { Jumlah } \\
\text { Produksi }\end{array}$ & 466 & 508 & 42 & 0.000 \\
\hline \multirow{5}{*}{ nput } & $\begin{array}{l}\text { Bahan } \\
\text { Baku }\end{array}$ & 22.860 .000 & $22.636 .666,667$ & 0.000 & - \\
\cline { 2 - 6 } & Upah & 36.000 .000 & 360.00 .000 & 0.000 & 0.000 \\
\cline { 2 - 6 } & $\begin{array}{l}\text { Biaya- } \\
\text { biaya lain }\end{array}$ & 10.800 .000 & 106.00 .000 & 0.000 & -200.000 \\
\hline
\end{tabular}

Sumber: Hasil Olah Data (2019)

Pada tabel 21 di atas dapat dilihat bahwa berdasarkan pengukuran efisiensi model VRS yang berorientasi pada output, usaha pembuatan tas bordir Aceh milik Marzuki memperoleh nilai skala efisiensi sebesar 0,917 yang berarti mengalami inefisiensi. Maka untuk meningkatkan nilai skala efisien menjadi satu (1) harus ditingkatkan sebesar $1-0,917=0,083$. Usaha pembuatan tas bordir Aceh milik Marzuki mengalami inefisiensi pada kedua output yaitu pendapatan dan jumlah produksi, namun usaha Marzuki masih dapat lebih mengefisienkan usaha pembuatan tas bordir Aceh dengan mengurangi pengeluaran pada kedua input yaitu bahan baku dan biaya-biaya lain sebesar slack movement.

Pada output pendapatan terlihat bahwa dengan input yang telah digunakan Marzuki memperoleh hasil sebesar Rp 116.500.000, sementara itu di target value (nilai target) yang harus dihasilkan oleh usaha Marzuki untuk output pendapatan adalah sebesar Rp 127.000.000. Oleh karenanya untuk meningkatkan nilai skala efisiensi usahanya, Marzuki harus meningkatkan pendapatannya sebesar Rp 127.000.000 - Rp $116.500 .000=\operatorname{Rp} 10.500 .000$, hal ini juga dapat dilihat pada besaran radial movement.

Sedangkan pada output jumlah produksi, usaha Marzuki telah menghasilkan sejumlah 466 unit, padahal usaha pembuatan tas bordir Aceh Marzuki masih dapat memaksimalkan jumlah produksi sebesar nilai target yaitu 508unit. Maka untuk meningkatkan nilai skala efisiensi usaha pembuatan tas bordir Aceh Marzuki harus meningkatkan jumlah produksinya sebesar radial movement yaitu 42 unit dari jumlah produksi yang telah dihasilkan guna mengefisienkan atau meningkatan nilai skala efisiensi usaha pembuatan tas bordir Aceh dengan slack movement sebesar Rp 0.

Untuk lebih mengefisienkan penggunaan input, usaha pembuatan tas bordir Aceh milik Marzuki dapat mengurangi input bahan baku sebesar Rp 223.333,333 dan input biaya-biaya 
lainnya sebesar Rp 200.000. Hal ini sesuai dengan nilai target dikurangi dengan nilai asli yang telah dihasilkan atau dapat juga dilihat pada besaran nilai slack movement.

\section{Sanusi}

Tabel 22

Nilai Original, Target, Radial Movement dan Slack Movement Input Output Usaha Tas Bordir Aceh Sanusi Yang Inefisiensi

\begin{tabular}{|c|c|c|c|c|c|}
\hline Variabel & $\begin{array}{l}\text { Nilai } \\
\text { Efisiensi }\end{array}$ & \multirow{2}{*}{$\begin{array}{l}\text { Original } \\
\text { Value }\end{array}$} & \multirow{2}{*}{ Target Value } & \multirow{2}{*}{$\begin{array}{l}\text { Radial } \\
\text { Movement }\end{array}$} & \multirow{2}{*}{$\begin{array}{l}\text { Slack } \\
\text { Movement }\end{array}$} \\
\hline $\begin{array}{l}2018- \\
2019\end{array}$ & 0,938 & & & & \\
\hline \multirow{2}{*}{ Putput } & Pendapatan & 119.000 .000 & $\begin{array}{l}126.804 .254,30 \\
\end{array}$ & $7.804 .254,30$ & 0.000 \\
\hline & $\begin{array}{l}\text { Jumlah } \\
\text { Produksi }\end{array}$ & 476 & 507,217 & 31.217 & 0.000 \\
\hline \multirow[t]{3}{*}{ nput } & $\begin{array}{l}\text { Bahan } \\
\text { Baku }\end{array}$ & 20.620 .000 & 20.620 .000 & 0.000 & 0.000 \\
\hline & Upah & 48.000 .000 & $36.913 .001,912$ & 0.000 & $\begin{array}{l} \\
11.086 .998,088\end{array}$ \\
\hline & $\begin{array}{l}\text { Biaya- } \\
\text { biaya lain }\end{array}$ & 12.000 .000 & 10.800 .000 & 0.000 & -1.200 .000 \\
\hline
\end{tabular}

Sumber: Hasil Olah Data (2019)

Pada tabel 22 di atas dapat dilihat bahwa berdasarkan pengukuran efisiensi model VRS yang berorientasi pada output, usaha pembuatan tas bordir Aceh milik Sanusi memperoleh nilai skala efisiensi sebesar 0,938 yang berarti mengalami inefisiensi. Maka untuk meningkatkan nilai skala efisien menjadi satu (1) harus ditingkatkan sebesar $1-0,938=0,062$. Usaha pembuatan tas bordir Aceh milik Sanusi mengalami inefisiensi pada kedua output yaitu pendapatan dan jumlah produksi, namun usaha Sanusi masih dapat lebih mengefisienkan usaha pembuatan tas bordir Aceh dengan mengurangi pengeluaran pada kedua input yaitu upah dan biaya-biaya lain sebesar slack movement. Adapun upaya yang dapat dilakukan oleh Sanusi adalah sebagai berikut.

Pada output pendapatan terlihat bahwa dengan input yang telah digunakan Sanusi memperoleh hasil sebesar Rp 119.000.000, sementara itu di target value (nilai target) yang harus dihasilkan oleh usaha Sanusi untuk output pendapatan adalah sebesar Rp 126.804.254,30. Oleh karenanya untuk meningkatkan nilai skala efisiensi usahanya, Sanusi harus meningkatkan pendapatannya sebesar - Rp 126.804.254,30 Rp119.000.000 = Rp 7.804.254,30. Hal ini juga dapat dilihat pada besaran radial movement .

Sedangkan pada output jumlah produksi, usaha Sanusi telah menghasilkan sejumlah 476unit, padahal usaha pembuatan tas bordir Aceh Sanusi masih dapat memaksimalkan jumlah produksi sebesar nilai target yaitu 507unit. Maka untuk meningkatkan nilai skala efisiensi usaha pembuatan tas bordir Aceh Sanusi harus meningkatkan jumlah produksinya sebesar radial movement yaitu 31 unit dari jumlah produksi yang telah dihasilkan guna mengefisienkan atau meningkatan nilai skala efisiensi usaha pembuatan tas bordir Aceh dengan slack movement sebesar Rp 0.

Untuk lebih mengefisienkan penggunaan input, usaha pembuatan tas bordir Aceh milik Sanusi dapat mengurangi input input upah sebesar Rp 11.086.998,088 dan input biaya-biaya lainnya sebesar Rp 1.200.000. Hal ini sesuai dengan nilai target dikurangi dengan nilai asli yang telah dihasilkan atau dapat juga dilihat pada besaran nilai slack movement.

\section{Jailani}

Tabel 23

Nilai Original, Target, Radial Movement dan Slack Movement Input Output Usaha Tas Bordir Aceh Jailani Yang Inefisiensi

\begin{tabular}{|l|l|l|l|l|l|}
\hline Variabel & $\begin{array}{l}\text { Nilai } \\
\text { Efisiensi }\end{array}$ & $\begin{array}{l}\text { Original } \\
\text { Value }\end{array}$ & Target Value & $\begin{array}{l}\text { Radial } \\
\text { Movement }\end{array}$ & $\begin{array}{l}\text { Slack } \\
\text { Movement }\end{array}$ \\
\hline $\begin{array}{l}\mathbf{2 0 1 8 -} \\
\text { 2019 }\end{array}$ & 0,958 & 120.250 .000 & 125.500 .000 & 5.250 .000 & 0.000 \\
\hline \multirow{3}{*}{ utput } & Pendapatan & & 502 & 21 & 0.000 \\
\cline { 2 - 6 } & $\begin{array}{l}\text { Jumlah } \\
\text { Produksi }\end{array}$ & 481 & $21.306 .666,667$ & 0.000 & $-653.333,333$ \\
& $\begin{array}{l}\text { Bahan } \\
\text { Baku }\end{array}$ & 21.960 .000 & 30.000 .000 & 0.000 & 0.000 \\
\cline { 2 - 5 } & Upah & 30.000 .000 & 3000 & -800.000 \\
\cline { 2 - 5 } & $\begin{array}{l}\text { Biaya- } \\
\text { biaya lain }\end{array}$ & 10.800 .000 & 10.000 .000 & 0.000 & \\
\hline
\end{tabular}

Sumber: Hasil Olah Data (2019)

Pada tabel 23 di atas dapat dilihat bahwa berdasarkan pengukuran efisiensi model VRS yang berorientasi pada output, usaha pembuatan tas bordir Aceh milik Jailani memperoleh nilai skala efisiensi sebesar 0,958 yang berarti mengalami inefisiensi. Maka untuk meningkatkan nilai skala efisien menjadi satu (1) harus ditingkatkan sebesar $1-0,958=0,042$. Usaha pembuatan tas bordir Aceh milik Jailani mengalami inefisiensi pada kedua output yaitu pendapatan dan jumlah produksi, namun usaha Jailani masih dapat lebih mengefisienkan usaha pembuatan tas bordir Aceh dengan mengurangi pengeluaran pada kedua input yaitu bahan baku dan biaya-biaya lain sebesar slack movement.

Pada output pendapatan terlihat bahwa dengan input yang telah digunakan Jailani memperoleh hasil sebesar Rp 120.250.000, sementara itu di target value (nilai target) yang harus dihasilkan oleh usaha Jailani untuk output pendapatan adalah sebesar Rp 125.500.000. Oleh 
karenanya untuk meningkatkan nilai skala efisiensi usahanya, Jailani harus meningkatkan pendapatannya sebesar Rp125.500.000 - Rp $120.250 .000=\operatorname{Rp} 5.250 .000$. Hal ini juga dapat dilihat pada besaran radial movement.

Sedangkan pada output jumlah produksi, usaha Jailani telah menghasilkan sejumlah 481unit, padahal usaha pembuatan tas bordir Aceh Jailani masih dapat memaksimalkan jumlah produksi sebesar nilai target yaitu 502unit. Maka untuk meningkatkan nilai skala efisiensi usaha pembuatan tas bordir Aceh Jailani harus meningkatkan jumlah produksinya sebesar radial movement yaitu 21 unit dari jumlah produksi yang telah dihasilkan guna mengefisienkan atau meningkatan nilai skala efisiensi usaha pembuatan tas bordir Aceh dengan slack movement sebesar Rp 0.

Untuk lebih mengefisienkan penggunaan input, usaha pembuatan tas bordir Aceh milik Jailani dapat mengurangi input bahan baku sebesar Rp 653.333,333 dan input biaya-biaya lainnya sebesar Rp 800.000. Hal ini sesuai dengan nilai target dikurangi dengan nilai asli yang telah dihasilkan atau dapat juga dilihat pada besaran nilai slack movement.

6. Nuria

\section{Tabel 24}

Nilai Original, Target, Radial Movement dan Slack Movement Input Output Usaha Tas Bordir Aceh Nuria Yang Inefisiensi

\begin{tabular}{|c|c|c|c|c|c|}
\hline Variabel & $\begin{array}{l}\text { Nilai } \\
\text { Efisiensi }\end{array}$ & \multirow{2}{*}{$\begin{array}{l}\text { Original } \\
\text { Value }\end{array}$} & \multirow[t]{2}{*}{ Target Value } & \multirow{2}{*}{$\begin{array}{l}\text { Radial } \\
\text { Movement }\end{array}$} & \multirow{2}{*}{$\begin{array}{l}\text { Slack } \\
\text { Movement }\end{array}$} \\
\hline 2018-2019 & 0,882 & & & & \\
\hline \multirow[t]{2}{*}{ putput } & Pendapatan & 112.500 .000 & 127.500 .000 & 15.000 .000 & 0.000 \\
\hline & $\begin{array}{l}\text { Jumlah } \\
\text { Produksi }\end{array}$ & 450 & 510 & 60 & 0.000 \\
\hline \multirow[t]{3}{*}{ nput } & $\begin{array}{l}\text { Bahan } \\
\text { Baku }\end{array}$ & 24.930 .000 & 23.080 .000 & 0.000 & -1.850 .000 \\
\hline & Upah & 60.000 .000 & 38.000 .000 & 0.000 & -22.000 .000 \\
\hline & $\begin{array}{l}\text { Biaya- } \\
\text { biaya lain }\end{array}$ & 12.000 .000 & 10.800 .000 & 0.000 & -1.200 .000 \\
\hline
\end{tabular}

Sumber: Hasil Olah Data (2019)

Pada tabel 24 di atas dapat dilihat bahwa berdasarkan pengukuran efisiensi model VRS yang berorientasi pada output, usaha pembuatan tas bordir Aceh milik Nuria memperoleh nilai skala efisiensi sebesar 0,882 yang berarti mengalami inefisiensi. Maka untuk meningkatkan nilai skala efisien menjadi satu (1) harus ditingkatkan sebesar $1-0,882=0,118$. Usaha pembuatan tas bordir Aceh milik Nuria mengalami inefisiensi pada kedua output yaitu pendapatan dan jumlah produksi, namun usaha Nuria masih dapat lebih mengefisienkan usaha pembuatan tas bordir Aceh dengan mengurangi pengeluaran pada ketiga input yaitu bahan baku, upah, dan biaya-biaya lain sebesar slack movement. Adapun upaya yang dapat dilakukan oleh Nuria adalah sebagai berikut.

Pada output pendapatan terlihat bahwa dengan input yang telah digunakan Nuria memperoleh hasil sebesar Rp 112.500.000, sementara itu di target value (nilai target) yang harus dihasilkan oleh usaha Nuria untuk output pendapatan adalah sebesar Rp 127.500.000. Oleh karenanya untuk meningkatkan nilai skala efisiensi usahanya, Nuria harus meningkatkan pendapatannya sebesar Rp 127.500.000 - Rp $112.500 .000=\operatorname{Rp} 15.000 .000$. Hal ini juga dapat dilihat pada besaran radial movement.

Sedangkan pada output jumlah produksi, usaha Nuria telah menghasilkan sejumlah 450unit, padahal usaha pembuatan tas bordir Aceh Nuria masih dapat memaksimalkan jumlah produksi sebesar nilai target yaitu 510 unit. Maka untuk meningkatkan nilai skala efisiensi usaha pembuatan tas bordir Aceh Nuria harus meningkatkan jumlah produksinya sebesar radial movement yaitu 60 unit dari jumlah produksi yang telah dihasilkan guna mengefisienkan atau meningkatan nilai skala efisiensi usaha pembuatan tas bordir Aceh dengan slack movement sebesar Rp 0.

Untuk lebih mengefisienkan penggunaan input, usaha pembuatan tas bordir Aceh milik Nuria dapat mengurangi input bahan baku sebesar Rp1.850.000, input upah sebesar Rp 22.000.000, dan input biaya-biaya lainnya sebesar Rp1.200.000. Hal ini sesuai dengan nilai target dikurangi dengan nilai asli yang telah dihasilkan atau dapat juga dilihat pada besaran nilai slack movement.

\section{Putrona}

Tabel25
Nilai Original, Target, Radial Movement dan Slack Movement Input Output Usaha Tas Bordir Aceh Putrona Yang Inefisiensi

\begin{tabular}{|l|l|l|l|l|l|}
\hline Variabel & $\begin{array}{l}\text { Nilai } \\
\text { Efisiensi }\end{array}$ & $\begin{array}{l}\text { Original } \\
\text { Value }\end{array}$ & Target Value & $\begin{array}{l}\text { Radial } \\
\text { Movement }\end{array}$ & $\begin{array}{l}\text { Slack } \\
\text { Movement }\end{array}$ \\
\hline $\begin{array}{l}\mathbf{2 0 1 8 -} \\
\mathbf{2 0 1 9}\end{array}$ & $\mathbf{0 , 9 3 9}$ & 116.750 .000 & $124.305 .970,15$ & $75.55 .970,15$ & 0.000 \\
\hline \multirow{2}{*}{ utput } & Pendapatan & 467 & 497,224 & 30,224 & 0.000 \\
\cline { 2 - 6 } & $\begin{array}{l}\text { Jumlah } \\
\text { Produksi }\end{array}$ & 40.290 .000 & 20.290 .000 & 0.000 & 0.000 \\
\hline nput & $\begin{array}{l}\text { Bahan } \\
\text { Baku }\end{array}$ & 20.290 & & - \\
\cline { 2 - 5 } & Upah & 30.000 .000 & $27.455 .223,88$ & 0.000 & $2.544 .776,12$ \\
\hline
\end{tabular}


Biaya-

\begin{tabular}{|l|l|}
\hline 9.600 .000 & 9.600 .000 \\
\hline
\end{tabular}

0.000

0.000

Sumber: Hasil Olah Data (2019)

Pada tabel 25 di atas dapat dilihat bahwa berdasarkan pengukuran efisiensi model VRS yang berorientasi pada output, usaha pembuatan tas bordir Aceh milik Putrona memperoleh nilai skala efisiensi sebesar 0,939 yang berarti mengalami inefisiensi. Maka untuk meningkatkan nilai skala efisien menjadi satu (1) harus ditingkatkan sebesar $1-0,939=0,061$. Usaha pembuatan tas bordir Aceh milik Putronamengalami inefisiensi pada kedua output yaitu pendapatan dan jumlah produksi, namun usaha Putrona masih dapat lebih mengefisienkan usaha pembuatan tas bordir Aceh dengan mengurangi pengeluaran pada input upah sebesar slack movement. Adapun upaya yang dapat dilakukan oleh Putrona adalah sebagai berikut.

Pada output pendapatan terlihat bahwa dengan input yang telah digunakan Putrona memperoleh hasil sebesar Rp 116.750.000, sementara itu di target value (nilai target) yang harus dihasilkan oleh usaha Putrona untuk output pendapatan adalah sebesar Rp 124.305.970,15. Oleh karenanya untuk meningkatkan nilai skala efisiensi usahanya, Putrona harus meningkatkan pendapatannya sebesar $\mathrm{Rp}$ 124.305.970,15Rp126.257.711,26 = Rp 75.55.970,15.Hal ini juga dapat dilihat pada besaran radial movement.

Sedangkan pada output jumlah produksi, usaha Putrona telah menghasilkan sejumlah 467 unit, padahal usaha pembuatan tas bordir Aceh Putrona masih dapat memaksimalkan jumlah produksi sebesar nilai target yaitu 497unit. Maka untuk meningkatkan nilai skala efisiensi usaha pembuatan tas bordir Aceh Putrona harus meningkatkan jumlah produksinya sebesar radial movement yaitu 30 unit dari jumlah produksi yang telah dihasilkan guna mengefisienkan atau meningkatan nilai skala efisiensi usaha pembuatan tas bordir Aceh dengan slack movement sebesar Rp 0 .

Untuk lebih mengefisienkan penggunaan input, usaha pembuatan tas bordir Aceh milik Putrona dapat mengurangi input upah sebesar $\mathrm{Rp}$ 2.544.776,12. Hal ini sesuai dengan nilai target dikurangi dengan nilai asli yang telah dihasilkan atau dapat juga dilihat pada besaran nilai slack movement.

\section{Pelita}

Tabel 26

Nilai Original, Target, Radial Movement dan Slack Movement Input Output Usaha Tas Bordir Aceh Pelita Yang Inefisiensi

\begin{tabular}{|l|l|l|l|l|l|}
\hline Variabel & $\begin{array}{l}\text { Nilai } \\
\text { Efisiensi }\end{array}$ & $\begin{array}{l}\text { Original } \\
\text { Value }\end{array}$ & Target Value & $\begin{array}{l}\text { Radial } \\
\text { Movement }\end{array}$ & $\begin{array}{l}\text { Slack } \\
\text { Movement }\end{array}$ \\
\hline 2018-2019 & $\mathbf{0 , 9 5 7}$ & 122.000 .000 & 127.500 .000 & 5.500 .000 & 0.000 \\
\hline \multirow{3}{*}{ nutput } & Pendapatan & & 510 & 22 & 0.000 \\
\cline { 2 - 5 } & $\begin{array}{l}\text { Jumlah } \\
\text { Produksi }\end{array}$ & 488 & 23.080 .000 & 0.000 & -60.000 \\
& $\begin{array}{l}\text { Bahan } \\
\text { Baku }\end{array}$ & 23.140 .000 & 38.000 .000 & 0.000 & -10.000 .000 \\
\cline { 2 - 5 } & Upah & 48.000 .000 & 10.800 .000 & 0.000 & 0.000 \\
\cline { 2 - 5 } & $\begin{array}{l}\text { Biaya- } \\
\text { biaya lain }\end{array}$ & 10.800 .000 & & & \\
\hline
\end{tabular}

Sumber: Hasil Olah Data (2019)

Pada tabel 26 di atas dapat dilihat bahwa berdasarkan pengukuran efisiensi model VRS yang berorientasi pada output, usaha pembuatan tas bordir Aceh milik Pelita memperoleh nilai skala efisiensi sebesar 0,957 yang berarti mengalami inefisiensi. Maka untuk meningkatkan nilai skala efisien menjadi satu (1) harus ditingkatkan sebesar $1-0,957=0,043$. Usaha pembuatan tas bordir Aceh milik Pelita mengalami inefisiensi pada kedua output yaitu pendapatan dan jumlah produksi, namun usaha Pelita masih dapat lebih mengefisienkan usaha pembuatan tas bordir Aceh dengan mengurangi pengeluaran pada kedua input yaitu bahan baku dan upah sebesar slack movement. Adapun upaya yang dapat dilakukan oleh Pelita adalah sebagai berikut.

Pada output pendapatan terlihat bahwa dengan input yang telah digunakan Pelita memperoleh hasil sebesar Rp 122.000.000, sementara itu di target value (nilai target) yang harus dihasilkan oleh usaha Pelita untuk output pendapatan adalah sebesar Rp 127.500.000. Oleh karenanya untuk meningkatkan nilai skala efisiensi usahanya, Pelita harus meningkatkan pendapatannya sebesar Rp 127.500.000 - Rp $122.000 .000=\operatorname{Rp~5.500.000.Hal~ini~juga~dapat~}$ dilihat pada besaran radial movement.

Sedangkan pada output jumlah produksi, usaha Pelita telah menghasilkan sejumlah 488unit, padahal usaha pembuatan tas bordir Aceh Pelita masih dapat memaksimalkan jumlah produksi sebesar nilai target yaitu 510 unit. Maka untuk meningkatkan nilai skala efisiensi usaha pembuatan tas bordir Aceh Pelita harus meningkatkan jumlah produksinya sebesar radial 
movement yaitu 22unit dari jumlah produksi yang telah dihasilkan guna mengefisienkan atau meningkatan nilai skala efisiensi usaha pembuatan tas bordir Aceh dengan slack movement sebesar Rp 0.

Untuk lebih mengefisienkan penggunaan input, usaha pembuatan tas bordir Aceh milik Pelita dapat mengurangi input bahan baku sebesar Rp 60.000 dan input upah sebesar Rp 10.000.000. Hal ini sesuai dengan nilai target dikurangi dengan nilai asli yang telah dihasilkan atau dapat juga dilihat pada besaran nilai slack movement.

\section{Pelita Sri Maryati}

\section{Tabel 27}

Nilai Original, Target, Radial Movement dan Slack Movement Input Output Usaha Tas Bordir Aceh Pelita Sri Maryati Yang Inefisiensi

\begin{tabular}{|c|c|c|c|c|c|}
\hline Variabel & $\begin{array}{l}\text { Nilai } \\
\text { Efisiensi }\end{array}$ & \multirow{2}{*}{$\begin{array}{l}\text { Original } \\
\text { Value }\end{array}$} & \multirow[t]{2}{*}{ Target Value } & \multirow{2}{*}{$\begin{array}{l}\text { Radial } \\
\text { Movement }\end{array}$} & \multirow{2}{*}{$\begin{array}{l}\text { Slack } \\
\text { Movement }\end{array}$} \\
\hline 2018-2019 & 0,909 & & & & \\
\hline \multirow[t]{2}{*}{ Putput } & Pendapatan & 114.750 .000 & $126.175 .651,79$ & $11.425 .651,79$ & 0.000 \\
\hline & $\begin{array}{l}\text { Jumlah } \\
\text { Produksi }\end{array}$ & 459 & 504,703 & 45.703 & 0.000 \\
\hline \multirow[t]{3}{*}{ nput } & $\begin{array}{l}\text { Bahan } \\
\text { Baku }\end{array}$ & 20.160 .000 & 20.160 .000 & 0.000 & 0.000 \\
\hline & Upah & 36.000 .000 & 36.000 .000 & 0.000 & 0.000 \\
\hline & $\begin{array}{l}\text { Biaya- } \\
\text { biaya lain }\end{array}$ & 10.800 .000 & $10.723 .110,915$ & 0.000 & $\begin{array}{l}- \\
76.889,085\end{array}$ \\
\hline
\end{tabular}

Sumber: Hasil Olah Data (2019)

Pada tabel 27 di atas dapat dilihat bahwa berdasarkan pengukuran efisiensi model VRS yang berorientasi pada output, usaha pembuatan tas bordir Aceh milik Pelita Sri Maryati memperoleh nilai skala efisiensi sebesar 0,909 yang berarti mengalami inefisiensi. Maka untuk meningkatkan nilai skala efisien menjadi satu (1) harus ditingkatkan sebesar $1-0,909=0,091$. Usaha pembuatan tas bordir Aceh milik Pelita Sri Maryati mengalami inefisiensi pada kedua output yaitu pendapatan dan jumlah produksi, namun usaha Pelita Sri Maryati masih dapat lebih mengefisienkan usaha pembuatan tas bordir Aceh dengan mengurangi pengeluaran pada input biayabiaya lain sebesar slack movement. Adapun upaya yang dapat dilakukan oleh Pelita Sri Maryati adalah sebagai berikut.

Pada output pendapatan terlihat bahwa dengan input yang telah digunakan Pelita Sri Maryati memperoleh hasil sebesar $\mathrm{Rp}$ 114.750.000, sementara itu di target value (nilai target) yang harus dihasilkan oleh usaha Pelita Sri Maryati untuk output pendapatan adalah sebesar Rp 126.175.651,79. Oleh karenanya untuk meningkatkan nilai skala efisiensi usahanya, Pelita Sri Maryati harus meningkatkan pendapatannya sebesar Rp 126.175.651,79- Rp 114.750.000 = Rp 11.425.651,79.Hal ini juga dapat dilihat pada besaran radial movement.

Sedangkan pada output jumlah produksi, usaha PelitaSri Maryati telah menghasilkan sejumlah 459unit, padahal usaha pembuatan tas bordir Aceh PelitaSri Maryati masih dapat memaksimalkan jumlah produksi sebesar nilai target yaitu 505 unit. Maka untuk meningkatkan nilai skala efisiensi usaha pembuatan tas bordir Aceh Pelita Sri Maryati harus meningkatkan jumlah produksinya sebesar radial movement yaitu 46unit dari jumlah produksi yang telah dihasilkan guna mengefisienkan atau meningkatan nilai skala efisiensi usaha pembuatan tas bordir Aceh dengan slack movement sebesar Rp 0.

Untuk lebih mengefisienkan penggunaan input, usaha pembuatan tas bordir Aceh milik Pelita Sri Maryati dapat mengurangi input biayabiaya lain sebesar Rp 76.889,085. Hal ini sesuai dengan nilai target dikurangi dengan nilai asli yang telah dihasilkan atau dapat juga dilihat pada besaran nilai slack movement.

\section{Sanyo Bag}

Tabel 28

Nilai Original, Target, Radial Movement dan Slack Movement Input Output Usaha Tas Bordir Aceh Sanyo Bag Yang Inefisiensi

\begin{tabular}{|l|l|l|l|l|l|}
\hline Variabel & $\begin{array}{l}\text { Nilai } \\
\text { Efisiensi }\end{array}$ & $\begin{array}{l}\text { Original } \\
\text { Value }\end{array}$ & Target Value & $\begin{array}{l}\text { Radial } \\
\text { Movement }\end{array}$ & $\begin{array}{l}\text { Slack } \\
\text { Movement }\end{array}$ \\
\hline 2018-2019 & $\mathbf{0 , 9 2 5}$ & 122.750 .000 & $126.038 .002,65$ & $3.288 .002,65$ & 0.000 \\
\hline \multirow{3}{*}{ nutput } & Pendapatan & & 504,152 & 13,152 & 0.000 \\
\cline { 2 - 5 } & $\begin{array}{l}\text { Jumlah } \\
\text { Produksi }\end{array}$ & 491 & 20.020 .000 & 0.000 & 0.000 \\
& $\begin{array}{l}\text { Bahan } \\
\text { Baku }\end{array}$ & 20.020 .000 & & & 0.000 \\
\cline { 2 - 5 } & Upah & 36.000 .000 & 36.000 .000 & 0.000 & - \\
\cline { 2 - 5 } & $\begin{array}{l}\text { Biaya- } \\
\text { biaya lain }\end{array}$ & 10.800 .000 & $10.730 .534,688$ & 0.000 & $69.465,312$ \\
\hline
\end{tabular}

Sumber: Hasil Olah Data (2019)

Pada tabel 28 di atas dapat dilihat bahwa berdasarkan pengukuran efisiensi model VRS yang berorientasi pada output, usaha pembuatan tas bordir Aceh milik Sanyo Bag memperoleh nilai skala efisiensi sebesar 0,925 yang berarti mengalami inefisiensi. Maka untuk meningkatkan nilai skala efisien menjadi satu (1) harus ditingkatkan sebesar $1-0,925=0,075$. Usaha pembuatan tas bordir Aceh milik Sanyo Bag mengalami inefisiensi pada kedua output yaitu pendapatan dan jumlah produksi, namun usaha Sanyo Bag masih dapat lebih mengefisienkan usaha pembuatan tas bordir Aceh dengan mengurangi pengeluaran pada input biaya-biaya lain sebesar slack movement. Adapun upaya yang 
dapat dilakukan oleh Sanyo Bag adalah sebagai berikut.

Pada output pendapatan terlihat bahwa dengan input yang telah digunakan Sanyo Bag memperoleh hasil sebesar $\mathrm{Rp}$ 122.750.000, sementara itu di target value (nilai target) yang harus dihasilkan oleh usaha Sanyo Bag untuk output pendapatan adalah sebesar $\mathrm{Rp}$ 126.038.002,65. Oleh karenanya untuk meningkatkan nilai skala efisiensi usahanya, Sanyo Bag harus meningkatkan pendapatannya sebesar Rp 126.038.002,65- Rp $122.750 .000=\mathrm{Rp}$ 3.288.002,65.Hal ini juga dapat dilihat pada besaran nilai radial movement.

Sedangkan pada output jumlah produksi, usaha Sanyo Bag telah menghasilkan sejumlah 491unit, padahal usaha pembuatan tas bordir Aceh Sanyo Bag masih dapat memaksimalkan jumlah produksi sebesar nilai target yaitu 504 unit. Maka untuk meningkatkan nilai skala efisiensi usaha pembuatan tas bordir Aceh Sanyo Bag harus meningkatkan jumlah produksinya sebesar radial movement yaitu 13unit dari jumlah produksi yang telah dihasilkan guna mengefisienkan atau meningkatan nilai skala efisiensi usaha pembuatan tas bordir Aceh dengan slack movement sebesar Rp 0.

Untuk lebih mengefisienkan penggunaan input, usaha pembuatan tas bordir Aceh milik Sanyo Bag dapat mengurangi input biaya-biaya lain sebesar Rp 69.465,312. Hal ini sesuai dengan nilai target dikurangi dengan nilai asli yang telah dihasilkan atau dapat juga dilihat pada besaran nilai slack movement.

\section{Naiart Cop Tah}

\section{Tabel 29}

Nilai Original, Target, Radial Movement dan Slack Movement Input Output Usaha Tas Bordir Aceh Naiart Cop Tah Yang Inefisien

\begin{tabular}{|c|c|c|c|c|c|}
\hline Variabel & $\begin{array}{l}\text { Nilai } \\
\text { Efisiensi }\end{array}$ & \multirow{2}{*}{$\begin{array}{l}\text { Original } \\
\text { Value }\end{array}$} & \multirow{2}{*}{ Target Value } & \multirow{2}{*}{$\begin{array}{l}\text { Radial } \\
\text { Movement }\end{array}$} & \multirow{2}{*}{$\begin{array}{l}\text { Slack } \\
\text { Movement }\end{array}$} \\
\hline $\begin{array}{l}2018- \\
2019\end{array}$ & 0,836 & & & & \\
\hline \multirow[t]{2}{*}{ utput } & Pendapatan & 123.750 .000 & $124.676 .470,59$ & $926.470,59$ & 0.000 \\
\hline & $\begin{array}{l}\text { Jumlah } \\
\text { Produksi }\end{array}$ & 495 & 498,706 & 3,706 & 0.000 \\
\hline \multirow[t]{3}{*}{ nput } & $\begin{array}{l}\text { Bahan } \\
\text { Baku } \\
\end{array}$ & 24.680 .000 & $21.132 .941,176$ & 0.000 & $-3.547 .058,824$ \\
\hline & Upah & 30.000 .000 & 30.000 .000 & 0.000 & 0.000 \\
\hline & $\begin{array}{l}\text { Biaya- } \\
\text { biaya lain }\end{array}$ & 9.600 .000 & 9.600 .000 & 0.000 & 0.000 \\
\hline
\end{tabular}

Sumber: Hasil Olah Data (2019)
Pada tabel 29 di atas dapat dilihat bahwa berdasarkan pengukuran efisiensi model VRS yang berorientasi pada output, usaha pembuatan tas bordir Aceh milik Naiart Cop Tah memperoleh nilai skala efisiensi sebesar 0,836 yang berarti mengalami inefisiensi. Maka untuk meningkatkan nilai skala efisien menjadi satu (1) harus ditingkatkan sebesar 1-0,836=0,164. Usaha pembuatan tas bordir Aceh milik Naiart Cop Tah mengalami inefisiensi pada output kedua output yaitu pendapatan dan jumlah produksi, namun usaha Naiart Cop Tah masih dapat lebih mengefisienkan usaha pembuatan tas bordir Aceh dengan mengurangi pengeluaran pada input bahan baku sebesar slack movement. Adapun upaya yang dapat dilakukan oleh Naiart Cop Tahadalah sebagai berikut.

Pada output pendapatan terlihat bahwa dengan input yang telah digunakan Naiart Cop Tahmemperoleh hasil sebesar Rp 123.750.000, sementara itu di target value (nilai target) yang harus dihasilkan oleh usaha Naiart Cop Tahuntuk output pendapatan adalah sebesar Rp 124.676.470,59. Oleh karenanya untuk meningkatkan nilai skala efisiensi usahanya, Naiart Cop Tah harus meningkatkan pendapatannya sebesar Rp 124.676.470,59- Rp $123.750 .000=\operatorname{Rp} 926.470,59$. Hal ini juga dapat dilihat pada besaran nilai radial movement.

Sedangkan pada output jumlah produksi, usaha Naiart Cop Tah telah menghasilkan sejumlah 495unit, padahal usaha pembuatan tas bordir Aceh Naiart Cop Tah masih dapat memaksimalkan jumlah produksi sebesar nilai target yaitu 499 unit. Maka untuk meningkatkan nilai skala efisiensi usaha pembuatan tas bordir Aceh Naiart Cop Tah harus meningkatkan jumlah produksinya sebesar radial movement yaitu 4unit dari jumlah produksi yang telah dihasilkan guna mengefisienkan atau meningkatan nilai skala efisiensi usaha pembuatan tas bordir Aceh dengan slack movement sebesar Rp 0.

Untuk lebih mengefisienkan penggunaan input, usaha pembuatan tas bordir Aceh milik Naiart Cop Tah dapat mengurangi input bahan baku sebesar Rp 3.547.058,824. Hal ini sesuai dengan nilai target dikurangi dengan nilai asli 
yang telah dihasilkan atau dapat juga dilihat pada besaran nilai slack movement.

\section{Nisa}

Tabel 30

Nilai Original, Target, Radial Movement dan Slack Movement Input Output Usaha Tas Bordir Aceh Nisa Yang Inefisiensi

\begin{tabular}{|l|l|l|l|l|l|}
\hline Variabel & $\begin{array}{l}\text { Nilai } \\
\text { Efisiensi }\end{array}$ & $\begin{array}{l}\text { Original } \\
\text { Value }\end{array}$ & Target Value & $\begin{array}{l}\text { Radial } \\
\text { Movement }\end{array}$ & $\begin{array}{l}\text { Slack } \\
\text { Movement }\end{array}$ \\
\hline 2018-2019 & 0,869 & 123.750 .000 & 127.500 .000 & 3.750 .000 & 0.000 \\
\hline putput & Pendapatan & 15 & 510 & 15 & 0.000 \\
\cline { 2 - 5 } & $\begin{array}{l}\text { Jumlah } \\
\text { Produksi }\end{array}$ & 495 & 23.080 .000 & 0.000 & -440.000 \\
\hline \multirow{3}{*nnn}{} & $\begin{array}{l}\text { Bahan } \\
\text { Baku }\end{array}$ & 23.520 .000 & 38.000 .000 & 0.000 & -4.000 .000 \\
\cline { 2 - 5 } & Upah & 42.000 .000 & 10.800 .000 & 0.000 & 0.000 \\
\cline { 2 - 5 } & $\begin{array}{l}\text { Biaya- } \\
\text { biaya lain }\end{array}$ & 10.800 .000 & & & \\
\hline
\end{tabular}

Sumber: Hasil Olah Data (2019)

Pada tabel 30 di atas dapat dilihat bahwa berdasarkan pengukuran efisiensi model VRS yang berorientasi pada output, usaha pembuatan tas bordir Aceh milik Nisa memperoleh nilai skala efisiensi sebesar 0,869 yang berarti mengalami inefisiensi. Maka untuk meningkatkan nilai skala efisien menjadi satu (1) harus ditingkatkan sebesar $1-0,869=0,131$. Usaha pembuatan tas bordir Aceh milik Nisa mengalami inefisiensi pada kedua output yaitu pendapatan dan jumlah produksi, namun usaha Nisa masih dapat lebih mengefisienkan usaha pembuatan tas bordir Aceh dengan mengurangi pengeluaran pada input bahan baku dan upah sebesar slack movement. Adapun upaya yang dapat dilakukan oleh Nisa adalah sebagai berikut.

Pada output pendapatan terlihat bahwa dengan input yang telah digunakan Nisa memperoleh hasil sebesar Rp 123.750.000, sementara itu di target value (nilai target) yang harus dihasilkan oleh usaha Nisa untuk output pendapatan adalah sebesar Rp 127.500.000. Oleh karenanya untuk meningkatkan nilai skala efisiensi usahanya, Nisa harus meningkatkan pendapatannya sebesar Rp 127.500.000 - Rp $123.750 .000=\operatorname{Rp} 3.750 .000$. Hal ini juga dapat dilihat pada besaran nilai radial movement.

Sedangkan pada output jumlah produksi, usaha Nisa telah menghasilkan sejumlah 495unit, padahal usaha pembuatan tas bordir Aceh Nisa masih dapat memaksimalkan jumlah produksi sebesar nilai target yaitu 510 unit. Maka untuk meningkatkan nilai skala efisiensi usaha pembuatan tas bordir Aceh Nisa harus meningkatkan jumlah produksinya sebesar radial movement yaitu 15unit dari jumlah produksi yang telah dihasilkan guna mengefisienkan atau meningkatan nilai skala efisiensi usaha pembuatan tas bordir Aceh dengan slack movement sebesar Rp 0.

Untuk lebih mengefisienkan penggunaan input, usaha pembuatan tas bordir Aceh milik Nisa dapat mengurangi input bahan baku sebesar Rp 440.000 dan input upah sebesar Rp 4.000.000. Hal ini sesuai dengan nilai target dikurangi dengan nilai asli yang telah dihasilkan atau dapat juga dilihat pada besaran nilai slack movement.

\section{Zaini}

Tabel 31

Nilai Original, Target, Radial Movement dan Slack Movement Input Output Usaha Tas Bordir Aceh Zaini Yang Inefisiensi

\begin{tabular}{|c|c|c|c|c|c|}
\hline Variabel & $\begin{array}{l}\text { Nilai } \\
\text { Efisiensi }\end{array}$ & \multirow{2}{*}{$\begin{array}{l}\text { Original } \\
\text { Value }\end{array}$} & \multirow{2}{*}{ Target Value } & \multirow{2}{*}{$\begin{array}{l}\text { Radial } \\
\text { Movement }\end{array}$} & \multirow{2}{*}{$\begin{array}{l}\text { Slack } \\
\text { Movement }\end{array}$} \\
\hline $\begin{array}{l}2018- \\
2019 \\
\end{array}$ & $\overline{0,934}$ & & & & \\
\hline \multirow[t]{2}{*}{ Dutput } & Pendapatan & 119.500 .000 & $126.072 .896,75$ & $6.572 .896,75$ & 0.000 \\
\hline & $\begin{array}{l}\text { Jumlah } \\
\text { Produksi }\end{array}$ & 478 & 504,292 & 26,292 & 0.000 \\
\hline \multirow[t]{3}{*}{ nput } & $\begin{array}{l}\text { Bahan } \\
\text { Baku }\end{array}$ & 19.940 .000 & 19.940 .000 & 0.000 & 0.000 \\
\hline & Upah & 48.000 .000 & $36.587 .954,111$ & 0.000 & $\begin{array}{l}11.412 .045,889 \\
\end{array}$ \\
\hline & $\begin{array}{l}\text { Biaya- } \\
\text { biaya lain }\end{array}$ & 10.800 .000 & 10.800 .000 & 0.000 & 0.000 \\
\hline
\end{tabular}

Sumber: Hasil Olah Data (2019)

Pada tabel 31 di atas dapat dilihat bahwa berdasarkan pengukuran efisiensi model VRS yang berorientasi pada output, usaha pembuatan tas bordir Aceh milik Zaini memperoleh nilai skala efisiensi sebesar 0,934 yang berarti mengalami inefisiensi. Maka untuk meningkatkan nilai skala efisien menjadi satu (1) harus ditingkatkan sebesar $1-0,934=0,066$. Usaha pembuatan tas bordir Aceh milik Zaini mengalami inefisiensi pada kedua output yaitu pendapatan dan jumlah produksi, namun usaha Zaini masih dapat lebih mengefisienkan usaha pembuatan tas bordir Aceh dengan mengurangi pengeluaran pada input upah sebesar slack movement. Adapun upaya yang dapat dilakukan oleh Zainiadalah sebagai berikut.

Pada output pendapatan terlihat bahwa dengan input yang telah digunakan Zainimemperoleh hasil sebesar Rp 119.500.000, sementara itu di target value (nilai target) yang harus dihasilkan oleh usaha Zainiuntuk output pendapatan adalah sebesar Rp 126.072.896,75. Oleh karenanya untuk meningkatkan nilai skala efisiensi usahanya, Zaini harus meningkatkan 
pendapatannya sebesar Rp 126.072.896,75- Rp $119.500 .000=\operatorname{Rp} 6.572 .896,75$. Hal ini juga dapat dilihat pada besaran nilai radial movement.

Sedangkan pada output jumlah produksi, usaha Zaini telah menghasilkan sejumlah 478unit, padahal usaha pembuatan tas bordir Aceh Zaini masih dapat memaksimalkan jumlah produksi sebesar nilai target yaitu 504 unit. Maka untuk meningkatkan nilai skala efisiensi usaha pembuatan tas bordir Aceh Zaini harus meningkatkan jumlah produksinya sebesar radial movement yaitu 26unit dari jumlah produksi yang telah dihasilkan guna mengefisienkan atau meningkatan nilai skala efisiensi usaha pembuatan tas bordir Aceh dengan slack movement sebesar Rp 0.

Untuk lebih mengefisienkan penggunaan input, usaha pembuatan tas bordir Aceh milik Zaini dapat mengurangi input upah sebesar $\mathrm{Rp}$ 11.412.045,889. Hal ini sesuai dengan nilai target dikurangi dengan nilai asli yang telah dihasilkan atau dapat juga dilihat pada besaran nilai slack movement

\section{KESIMPULAN}

Dari hasil penelitian tersebut mengenai efisiensi dalam pembuatan tas bordir Aceh di Gampong Ulee Madon Kecamatan Muara Batu Kabupaten Aceh Utara maka dapat disimpulkan bahwa.

1. Dari hasil pengujian CRS - Output Oriented, hanya 4 DMU (Maryana, Nadia, Rolan dan Anwar) yang efesien dan secara rata-rata masih belum efesien dari keseluruhan DMU yang berjumlah 20 DMU.

2. Dari hasil pengujian VRS - Output Oriented, hanya 7 DMU (Nyan Cut, Maryana, Nadia, Nurjani, Bungong Rauza, Rolan dan Anwar) yang efesien dan secara rata-rata masih belum efesien dari keseluruhan DMU yang berjumlah 20 DMU.

\section{SARAN}

1. Diharapkan kepada pemilik usaha khususnya pemilik usaha pembuatan tas bordir Aceh agar dapat menekan dan mengoptimalkan pengeluaran pada input produksi agar dapat meningkatkan output pada produksi tersebut.

2. Diharapkan kepada pemerintah agar dapat memberikan bantuan serta pengembangan keahlian dan membuka jalan agar produk lokal dapat diperdagangkan secara internasional.

\section{KEPUSTAKAAN}

Afzalur, R. (2011). Doktrin Ekonomi Islam Jilid 1. Dana Bhakti Wakaf.

Andriyani, D., Munandar, M., \& Fuadi, F. (2020). Analisis Efisiensi Teknis Industri Perabot di Kecamatan Jeumpa Kabupaten Bireuen dengan Data Envelopment Analysis (DEA) Method. Jurnal EMT KITA, 4(2), 138. https://doi.org/10.35870/emt.v4i2.160

Bustami, \& Nurlela. (2010). Akuntansi Biaya Edisi kedua. Mitra Wacana Media.

Carter, et al. (2004). Akuntansi Biaya Edisi 13 Penerjemah Krista. Salemba Empat.

Dari, F. T. W. (2018). Analisis Efisiensi Teknis Usaha Industri Kreatif Di Kecamatan Laweyan Dengan Metode Data Envelopment Analysis. Jurnal Ekonomi Pembangunan.

Eddy, H. (2010). Manajemen Operasi, ed: Revisi. Gramedia.

Ferguson, C. E., \& Gould, J. P. (1975). Micro Economics Theory.

Hafidoh. (2015). Pengaruh Pemanfaatan Dana Zakat Produktif Terhadap Tingkat Penghasilan Mustahik di Pos Keadilan Peduli Ummat (PKPU).

Hanafie, R. (2010). Pengantar Ekonomi Pertanian. ANDI.

Hansen, et al. (2013). Akuntansi Manajemen. Edisi 8 diterjemahkan oleh Deny Arnos Kwary. Salemba Empat.

Hidayah, N. (2014). STUDI KOMPARATIF TINGKAT EFISIENSI PERBANKAN KONVENSIONAL DAN PERBANKAN SYARIAH DI INDONESIA.

Horngen, et Al. (2009). Akuntansi Keuangan. Edisi IFRS, Edisi Kedelapan, Jilid 2. Erlangga.

Marta, S., \& Erza, O. (2010). Analisis Efisiensi Industri Gula Di Indonesia Dengan Metode Data Envelopment Analysis (DEA) Tahun 2001-2010. Jurnal Media Ekonomi, 18(3).

Mihai, D., \& Dona, I. (2014). The Efficiency Forecast Of Rural Human Resources Use By The Data Envelopment Analysis Approach. 14(4), 165-168. 
Muharam, H., \& Pusvitasari, R. (2007). Analisis

Perbandingan Efisiensi Bank Syariah di

Indonesia Dengan Metode Data Envelopment

Analysis (periode Tahun 2005). II(3), 80-116.

Pertiwi, P. (2015). Analisis Faktor-Faktor Yang Mempengaruhi Pendapatan Tenaga Kerja di Daerah Istimewah Yogyakarta.

Setiawan, A. B., \& Prajanti, S. D. W. (2011).

Analisis Efisiensi Penggunaan Faktor-Faktor

Produksi Usaha Tani Jagung Di Kabupaten

Grobogan Tahun 2008. Jurnal Ekonomi

Pembangunan.

Sukirno, S. (2012). Makroekonomi Teori

Pengantar Edisi Ketiga. Rajawali Pers.

Todaro, M. (2000). Pembangunan Ekonomi (edisi kesembilan, jilid I). Erlangga.

Wajdi, M. F. (2012). Analisis Efisiensi Industri Kecil Berdasarkan Analisis Stochastic Frontier. Jurnal Manajemen.

Winanthi, S. (2018). Analisis Efisiensi Keuangan Klaster Umkm Perikanan Di Kabupaten Sragen Menggunakan Metode DEA (Data

Envelopment Analysis). Jurnal Manajemen2.

Wulandari, A. A. R., \& Darsana, I. B. (2017).

Pengaruh Modal, Tenaga Kerja , Dan Lama

Usaha Terhadap Pendapatan Pengrajin

Industri Kerajinan Anyaman Di Desa Bona

Kecamatan Blahbatuh Kabupaten Gianyar. EJurnal Ep Unud, 6(4), 564-596. 